\title{
Current Progress in Adipose Tissue Biology: Implications in Obesity and Its Comorbidities
}

\author{
Anna Meiliana ${ }^{1,2 *}$, Nurrani Mustika Dewi², Andi Wijaya ${ }^{1,2}$ \\ ${ }^{1}$ Postgraduate Program in Clinical Pharmacy, Padjadjaran University, Jl. Eijkman No.38, Bandung, Indonesia \\ ${ }^{2}$ Prodia Clinical Laboratory, Jl. Cisangkuy No.2, Bandung, Indonesia \\ ${ }^{*}$ Corresponding author. E-mail: anna.meiliana@prodia.co.id
}

Received date: Feb 14, 2020; Revised date: May 20, 2019; Accepted date: May 25, 2019

\section{Abstract}

$\mathrm{B}$ ACKGROUND: Obesity has been decades become a highly interest study, accompanied by the realization that adipose tissue (AT) plays a major role in the regulation of metabolic function.

CONTENT: In past few years, adipocytes classification, development, and differentiation has been significant changes. The white adipose tissue (WAT) can transform to a phenotype like brown adipose (BAT) type and function. Exercise and cold induction were the most common factor for fat browning; however batokines such as fibroblast growth factor (FGF)-21, interleukin (IL)-6, Slit homolog 2 protein (SLIT2)-C, and Meteorin-like protein (METRNL) perform a beneficial browning action by increasing

\section{Introduction}

The prevalence of obesity keeps increasing worldwide, bring along the metabolic diseases as its consequences. Researchers keep their attention to the low-grade, chronic inflammation, suspected as the underlying mechanisms of obesity and its co-morbidities, including type 2 diabetes mellitus (T2DM), nonalcoholic fatty liver disease (NAFLD), steatohepatitis, asthma, cancer, cardiovascular diseases (CVD) and neurodegenerative diseases.(1)

Adipocytes was previously known as a storage of excessive energy we consumed, with the help of insulin, change nutrients into triglycerides or glycogen in adipocytes and myocytes.(2) Adipocytes are able to sense energy storage in a cell-autonomous manner, and secretes some peroxisome proliferator-activated receptor gamma coactivator (PGC)-1 $\alpha$ protein levels, a key factor to stimulate mitochondrial biogenesis and uncoupling Protein 1 (UCP1) transcription, thus change the WAT phenotype into beige.

SUMMARY: AT recently known as a complex organ, not only bearing a storage function but as well as the master regulator of energy balance and nutritional homeostasis; brown and beige fat express constitutively high levels of thermogenic genes and raise our expectation on new strategies for fighting obesity and metabolic disorders.

KEYWORDS: obesity, white adipose tissue, brown adipose tissue, beige adipose tissue, inflammation, IR, metabolic disease

Indones Biomed J. 2020; 12(2): 85-101

hormones to manage food intake signals at the sympathetic nervous system.(3-5) This action will release adrenaline and noradrenaline from nerve terminals in adipose tissue (AT), and induce lipolysis and thermogenic processes via $\beta$-adrenergic receptors activating on adipocytes.(4-6) The closed-loop brain-adipocyte axis presents the adipocyte crosstalk with other tissues to control energy storage and mobilization.(7) Evidently, the role of adipocytes in managing systemic energy metabolism is not as simple as that, many factors and mechanisms are involved, for instance some protein expressed by the adipocytes including adiponectin and fibroblast growth factor (FGF)21 , as well as cytokines and inflammatory proteins (8), and the thermogenesis process performed by brown adipocytes.

Brown Adipose Tissue (BAT), are so-called due to its brownish color, results from a high mitochondrial content 
and multilocular lipid droplets to perform its thermogenesis role. BAT is abundant in rodents and infant humans, the amounts reduced as a human grows adult but not diminished. (9-11) Recent findings in rodents and human introduced the identification of beige adipocytes within subcutaneous white adipose depots, add more complexity to the thermogenic program. $(3,12)$ Beige adipocytes differentiation was affected by various afferent and hormonal signals, involving the innate immune system in response to energy status. $(13,14)$ This lead to an interesting targets to resolve the problem of obesity and its co-morbidities.(15)

\section{Adipose Tissue Dysfunction in Obesity}

AT defined to be dysfunction when it can no longer maintain the systemic metabolic homeostasis. The dysfunction pathogenesis mechanisms grouped into three main contributors: unresolved inflammation, inappropriate extracellular matrix (ECM) remodeling and insufficient angiogenic potential. Those three mechanisms interact in a linier model. When nutrient intake is excess, and stored in the adipocytes, the cells will expand and reach its limit, thus the diffusional limit of oxygen touch its limit. A mild hypoxia will occur, induce stress signal to start angiogenesis and remodeling of the ECM to facilitate further expansion of AT (Figure 1). Until here, this process still regarded as a "healthy AT expansion". However, a chronic overnutrition could lead in an inadequate angiogenic due to persistent hypoxia, and lead into inflammation, fibrosis, cellular senescence, and necrotic adipocyte death. The unhealthy AT expansion in the end will lead to chronic metabolic disturbances. Therefore, we need to understand the coordination of these triad as the resident of AT, including adipocytes, immune cells, endothelial cells, and fibroblasts, some examples are shown in Figure 1.(16)

The precise triggers of obesity-associated inflammation were not entirely understood. However, several potential mechanisms theories were developed, involving the gutderived substance, and dietary component or metabolite. In our current understanding, the rapid expansion of AT in obesity will release intrinsic survival signals such as adipocyte death, hypoxia and mechano-transduction arising from interactions between the cell and the ECM, which might trigger an inflammatory response.(15) The signals expressed by dying adipocytes wish to solve their persistent hypoxia, but apparently invite immune cells and also recruit macrophages from blood monocytes to AT. The

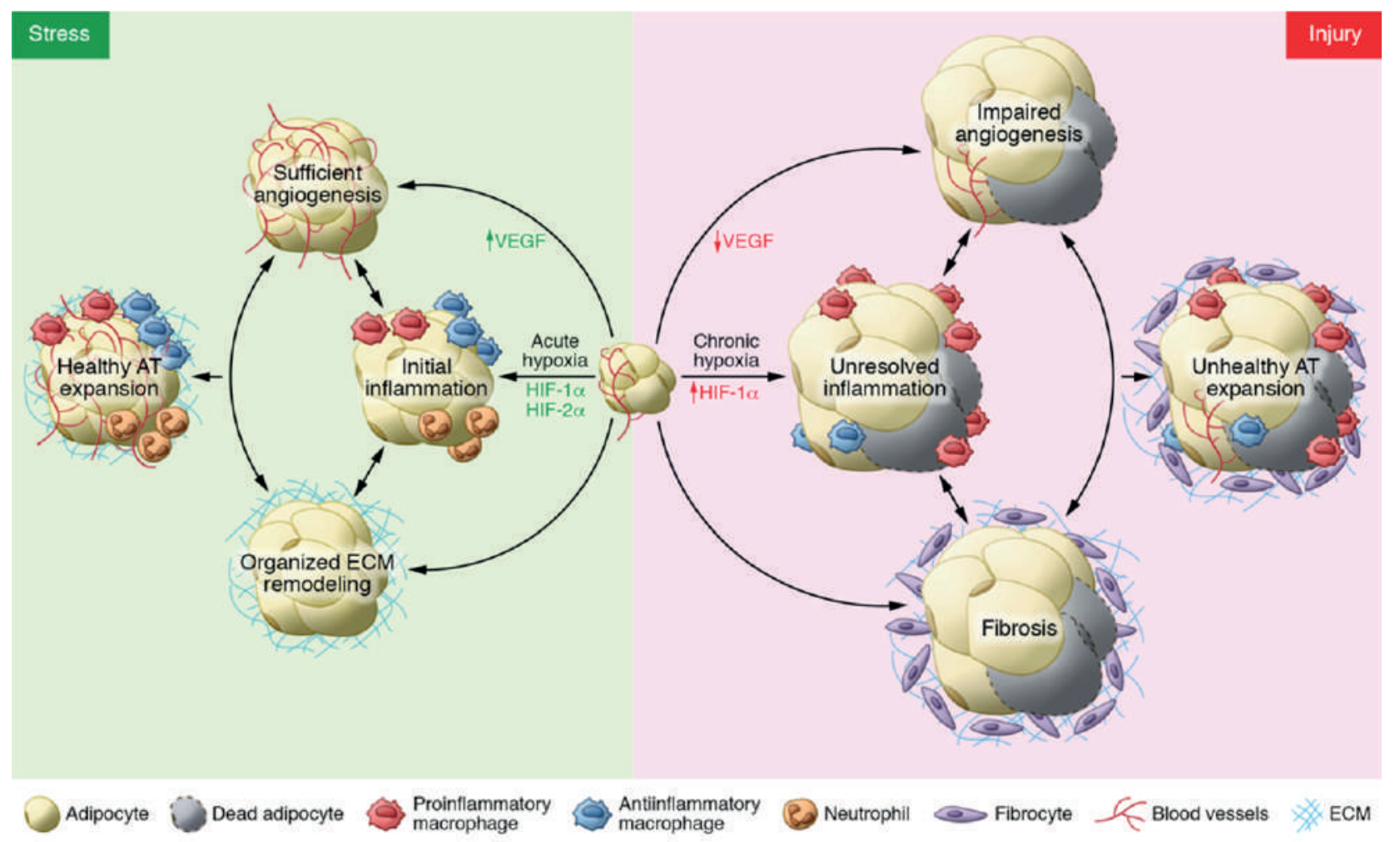

Figure 1. The complex contributions of angiogenesis, inflammation, and fibrosis in healthy and unhealthy adipose tissue expansion. VEGF: vascular endothelial growth factor; HIF: hypoxia-inducible factors; ECM: extracellular matrix.(16) (Adopted with permission from American Society for Clinical Investigation). 
M1 macrophages proliferate in crown-like structures as seen in histology containing F4/80-positive immune cells, and move throughout AT, amplify the inflammatory signals around AT, and invites more macrophages to join. This mechanism considered as the major driver of inflammation in AT dysfunction.(17-19) Stressed adipocytes express signals from damage-associated molecular patterns that sensed by the nucleotide oligomerization domain (NOD)like receptor (NLR) family of pattern recognition receptors (PRRs).(20) Activated NLR mobilize leukocytes to limit tissue damage. $(21,22)$ NLRs also activates the NOD-like receptor protein 3 (NLRP3) inflammasome (also known as cryopyrin) in macrophages and promote the expression of interleukin (IL)-1 $\beta$ and IL-18 via caspase 1.(23) However, adipocytes also secrete pro-inflammatory mediators (cytokines, chemokines, and adipokines) and in larger amounts compared with immune cells.(24)

Inadequate oxygen supply in the development of obesity $(25,26)$ activates the transcription factor hypoxiainducible factor (HIF)-1 $\alpha$ which induces cell death and further release of pro-inflammatory cytokines (27) and "self" antigens that stimulate class switch and the production of IgG pathogenic antibodies (28). The phenomenon describes a crosstalk between adipocytes and the immune cells which establish a chronic inflammation in obese AT, and possibly lead to insulin resistance (IR). Most macrophage in AT are M1 type or the classically activated macrophage. Hypoxia, via HIF-1 $\alpha$, potentiates glycolysis. Glycolysis activates M1 inflammatory function, and induces glucose transporter expression and glucose intakes and utilizations in AT. $(29,30)$ The inflammasome NLRP3 in M1 macrophages activates caspase 1 and the secretion of IL-1 $\beta$ (31), which is toxic to pancreatic $\beta$-cells and induces IR (32), as some studies reported increased inflammasome activity in monocytederived macrophages (33). On the contrary, M2 macrophages or alternative activated macrophages is associated to antiinflammatory properties. Hence, a reduce in a reduced ratio of pro-inflammatory M1-like adipose tissue macrophages (ATMs) to anti-inflammatory M2-like ATMs ratio indicate a phenotypic switch of AT macrophages which correlated to a pathophysiologic in AT health function.(25)

Another potential mechanism for inflammation in adipocyte is mechanical stress. In response to obesity, adipocyte needs to differentiate and expand, involving an interaction with their basement membrane and ECM. Cell shape is able to utilize relays that depend on the actin cytoskeleton to regulate gene expression in numerous cell systems.(33) In addition to adipocytes, AT consist of a dense network of ECM proteins, particularly collagen 1.(34)
Excess triglycerides storage in adipocytes in the ECMfixed environment could lead mechanical stress. Indeed, inactivation of genes involved in collagens formation or degradation, particularly matrix metallopeptidase (MMP)14, will affect adipocyte function, lipid synthesis and storage, and overall energy metabolism.(35) Some significant contributor to inflammation related to aging process are cell senescence, the acquisition of the senescence-associated secretory phenotype (SASP) by fibroblasts (36) and endothelial (37) and immune cells (38) Cellular senescence is defined as irreversible cell cycle arrest driven by a variety of mechanisms, means that the cell ages and permanently stops dividing but does not die. Activated senescence and energy-sensing signals cause dysregulated function of terminally differentiated $\mathrm{B}, \mathrm{T}$, and NK cells.

Bacteroidetes, known as beneficial bacteria that keeps you lean, versus Firmicutes, nicknamed as the negative bacteria, known to have an altered composition in obese and T2DM subjects either in human or animal. $(39,40)$ T-bet regulates mucosal $\mathrm{T}$ cell activation.(41) Gut microflora composition will be altered if T-bet is deficient, and lead to inflammation and metabolic processes that regulate T2DM. Fat-associated lymphoid clusters (FALCs), a new lymphoid tissue recently identified in the mesenteric AT of mice and humans, known to be rapidly induced after inflammatory stimuli in AT, and support B cell proliferation and differentiation regulating antibody production. $(42,43)$ Chronic low-grade (sterile) inflammation, also known as metaflammation (metabolic inflammation) has become one characteristic in obesity, which leads the transition of obese metabolism from normal to IR (44), with metabolic hallmarks as high levels of lipids, free fatty acids (FFAs), glucose, and reactive oxygen species (ROS). Some initiators of obesity-associated inflammation in adipocytes is shown in Figure 2.

Evidences showed association between inflammation and IR. Obese individuals with IR clearly exhibit a high degree of AT inflammation, compare to the obese with sensitive insulin. $(45,46)$ Some molecular signaling pathways link the inflammation and metabolism. For instances, knocking out key pathways for inflammatory signaling in obese mice, including components of the nuclear factor kappa B (NF$\kappa B)(46)$ and c-Jun N-terminal kinase (JNK) (47) pathways, as well as other molecules such as scaffolding proteins and cytokines, will block the link between obesity into IR either directly or indirectly. $(23,48,49)$

The nutrient storage in adipocyte is autoregulated by anabolic (insulin) and catabolic (leptin or catecholamine) signals. Resistance or failed response of adipocyte to 


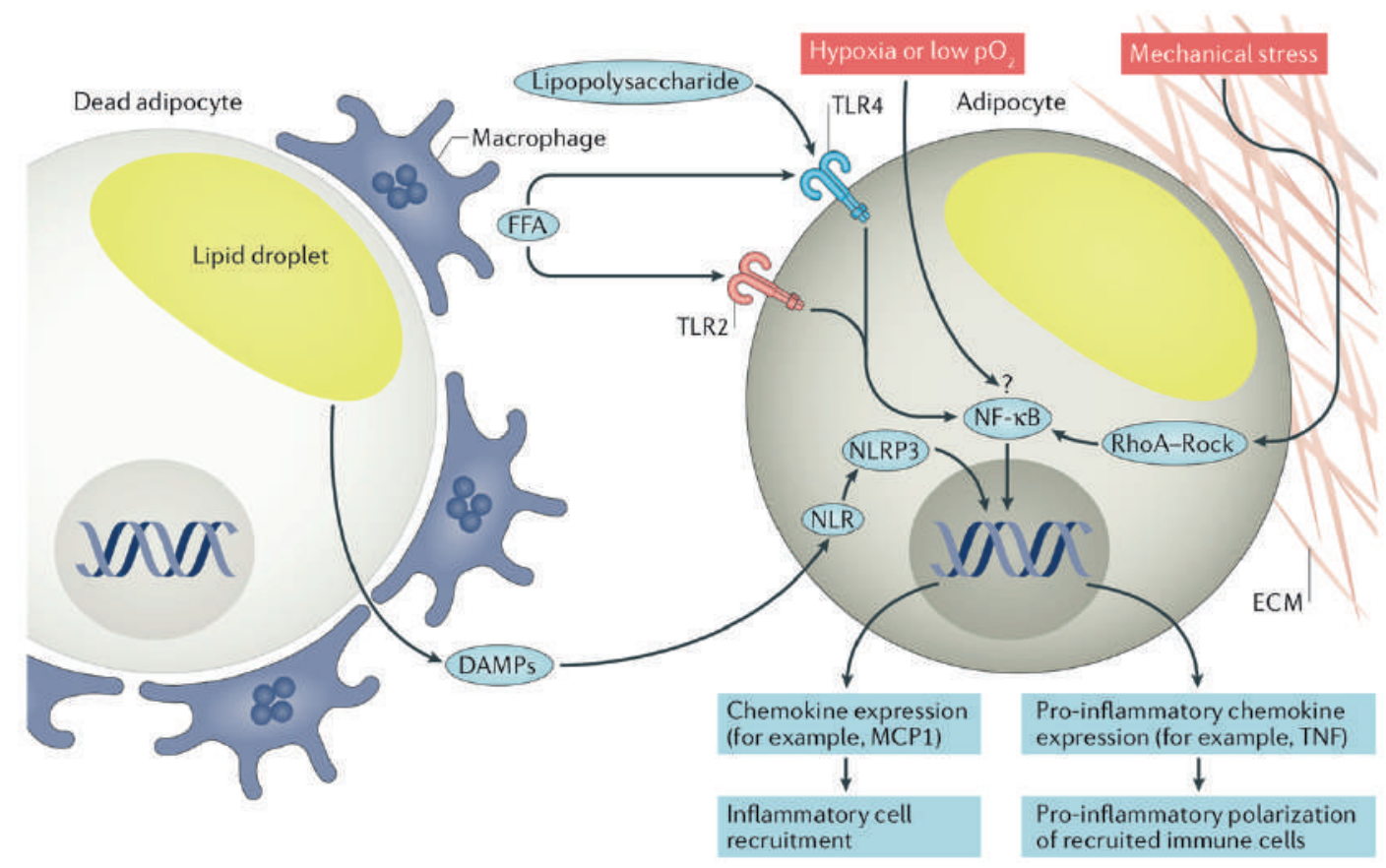

Figure 2. Initiators of obesity-associated inflammation in adipocytes. FFA: free fatty acid; TLR: toll-like receptor; ECM: extracellular matrix; NLR: nucleotide oligomerization domain-like receptor; NLRP3: NLR protein 3; NF-кB: nuclear factor kappa B; DAMP: danger-associated molecular pattern.(15) (Adopted with permission from Springer Nature).

catabolic signals stimulate the excess preservation of energy, associated with obesity.(51-53) Fortunately, resistance to any of these signals is metabolically flexible. $(51,54)$ Recent investigations moreover showed the relationship between inflammation and immune activation to long-term metabolic disease outcome lead a more comprehensive view for the effective therapeutic intervention.(27) Figure 3 shows the roles of ATM on obesity and its consequences in insulin resistance, metabolic syndrome and cardiometabolic risk.

\section{Advances in The Understanding of Adipose Tissue Biology}

The role of AT was not thought to be linked to metabolism in any possible way. Until the late 1940s, AT was characterized as a form of connective tissue that contains lipid droplets. The understanding progressively improved to be the storage organ after feeding and the "warehouse" of energy at fasting by releasing FFAs. The discovery of adiposederived serum factors like adipsin, tumor necrosis factor (TNF)- $\alpha$, and leptin, began in the late 1980s to mid 1990s, lead a new thought of AT as an endocrine organ and have center role in homeostasis. Until currently, studies on the AT developmental, functional, and pathophysiological have expanded markedly.
AT has a very unique feature, which is the capability to expand its dimension, either by increasing the single cell size (hypertrophy), or by recruiting new adipocytes from the resident pool of progenitors (hyperplasia). AT is the only non-neoplastic tissue having this capacity in this degree. Hypertrophy is the first mechanism occurred to compensate the overnutrition. Once the cell reached its critical threshold ( $\sim 0.7-0.8 \mu \mathrm{g} / \mathrm{cell})$, signals will be sent to induce proliferation and/or differentiation of preadipocytes into new adipocytes. Once adipocytes were attained, they were hard to eliminate. Only $\sim 8 \%$ of human subcutaneous total number of adipocytes turn over each year. Even in significant weight loss, adipocyte volume will be reduced, but not the overall number.(55-57) Adipocytes may die via necrosis or apoptosis, we know that macrophages is the star player in this process, but how the process contributes is not clear.(17)

Traditionally, positive energy balance equation become the benchmark that determine the adipogenesis, either due to overnutrition or reduced of energy expenditure and result in excess calories. Supposedly, we could align the same theory for any molecular effectors that induced positive energy balance by increased food intake or reduced energy expenditure. New adipocytes formation could be considered as an adaptive way to handling the increased calories safely. AT capability to change its size requires a 


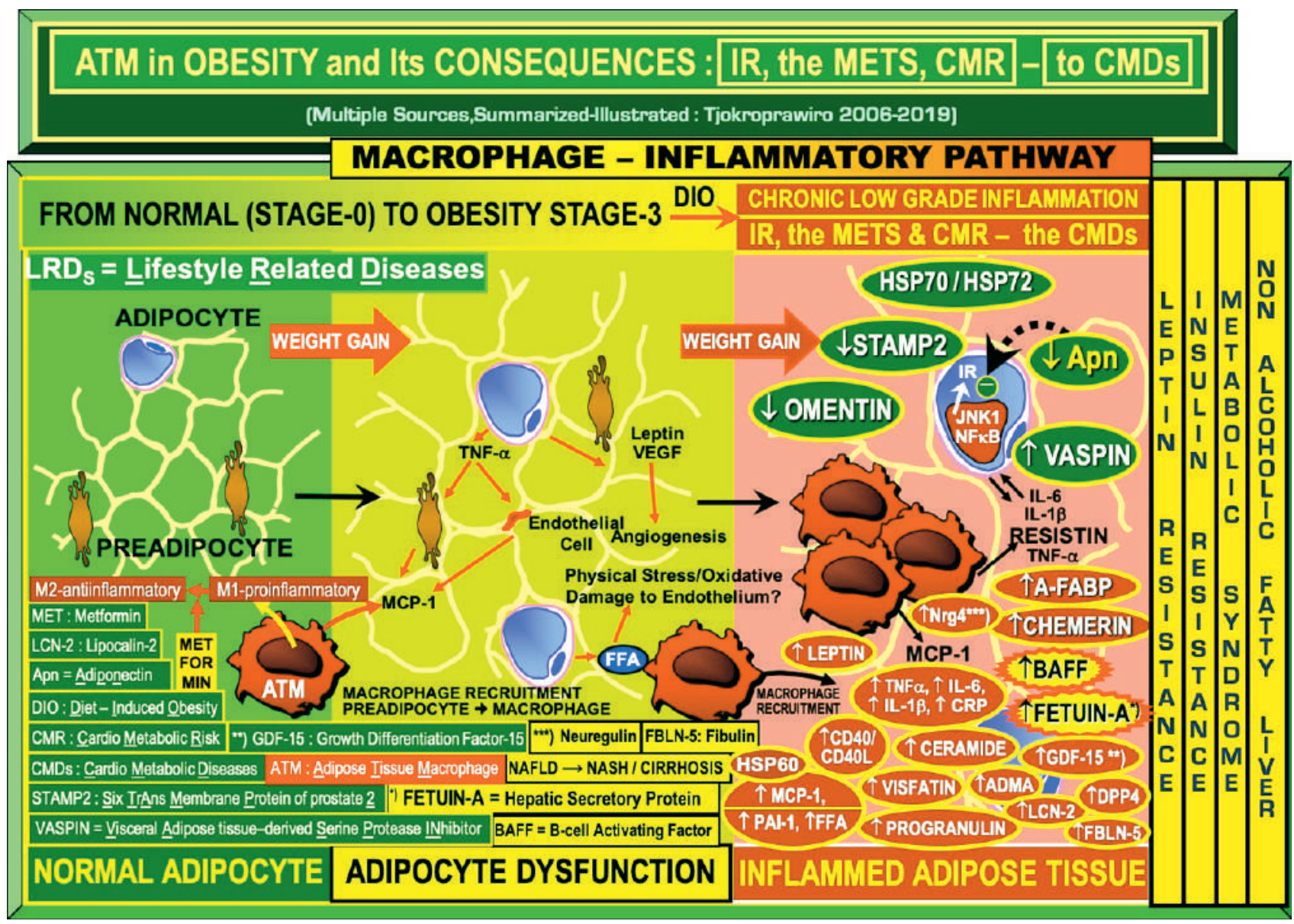

Figure 3. Adipose tissue macrophages on obesity and its consequences in insulin resistance, metabolic syndrome and cardiometabolic risks and diseases.(51) (Adopted with permission from PIT PERKENI).

unique capacity to remodel. Current evidences showed that dysfunction in AT remodeling become the hallmark events associating obesity with metabolic diseases.(58) AT remodeling concepts play the role in AT depots response to nutrient excess or deficiency.(59-62) Remodeling can be simply described as the changes in the cellular composition of the AT stromal cell network, in order to expand or contract AT. $(61,62)$ The process of remodeling occurred by deposition and breakdown of the non-cellular components' structures of AT, such as ECM. Besides nutrition, remodeling could also be induced by both physiological/ adaptive settings (e.g., embryonic development, puberty, pregnancy, and weight loss) or pathologic settings (e.g., obesity or lipodystrophy).(60)

Adipocytes hypertrophy and hyperplasia cannot be separated from the event of hypoxia, almost parallels to tumor biology theory, where the tissue needs to expand rapidly and demands to outgrow tissue's blood supply. In the effort of vascularization during AT expansion, hypoxia may develop.(63) Several proposed mechanism involving the actions of HIF- $1 \alpha$, suppression of $\beta$-oxidation via transcriptional repression of Sirtuin (SIRT)1, and deacetylation and activation of peroxisome proliferatoractivated receptor gamma (PPAR- $\gamma)$ coactivator 1 alpha (PGC-1 $\alpha$ ) (64), thus downregulating adiponectin and enhanced fibrosis and inflammation (65).

Another study presented FGF1 as a critical mediator of adipose remodeling. The adipose morphology in the $\mathrm{FGF}^{-1 /}$ mice were dramatically altered upon chronic overfeeding or fasting, accompanied by IR and dysglycemia.(1) A subgroup of obese subjects called themselves as the metabolically healthy obese (MHO). Marked by Col6a1-deficient and others with similar features they tend to have reduced visceral adiposity, increased adiponectin levels, reduced fibrosis and inflammation, and improved glucose and lipid homeostasis relative to other equally obese subjects.(66) MHO subject tends to have smaller adipocytes (67), suggest that in adipogenesis, numerous and smaller adipocytes have a better glucose uptake feature and a healthy adipokine profile, result in a healthier metabolic obese.

Adipocytes develop from preadipocytes, which was derived from precursor cells with various disconcert name 
in different literatures.(68) The most common name is stromal-vascular fraction (SVF). It could be separated from mature adipocytes by collagenase digestion and low-speed centrifugation. When cultured ex vivo, SVF separated into blood cells, endothelial cells, and other nonfibroblastic cells which do not attach to the dish, and the remains which could almost completely differentiated, by addition of hormonal cocktail that typically includes insulin, a glucocorticoid, a phosphodiesterase inhibitor, and often a PPAR- $\gamma$ agonist.(69)

The origin root of adipocyte is ectodermal.(70) In the cephalic region, neurectoderm arises into mesenchyme, which is primarily of mesodermal origin, and later develop into adipocyte. The fat pad consists of brown fat and white fat, suspected to share a common precursor but with different developmental pattern. However, later findings shown that classical brown fat derive from the same or very similar precursors with muscle cells, after the identification of the transcriptional cofactor PRD1-BF-1-RIZ1 homologous domain-containing protein-16 (PRDM16) as a dominant regulator of the brown fat program.(71) Altricial mammals such as mice and rats, which have a short gestation period and are born with an immature hypothalamic-pituitaryadrenal (HPA) axis keep their body warm after born by huddling in the nest and not by using non-shivering thermogenesis, mainly through metabolism in brown fat. Beige adipocytes have the morphological appearance of a transition form between white and brown fat. However, it was not derived from the same Pax $7^{+} \mathrm{Myf} 5^{+}$precursor cells which give rise to classic interscapular BAT (72), shown that both were distinct cell types. A major theory proposed these cells arise from transdifferentiation of existing mature white adipocytes, coherent with an observation that cold exposure or treatment with a $\beta 3$ agonist does not induce cellular proliferation in the newly browned fat pad. $(73,74)$

Both adipocytes and skeletal muscle derive from mesenchymal cells. They are intertwined in several interesting ways, share overlapping gene expression patterns, and skeletal muscle and brown fat shared lineage through a $\mathrm{Myf5}^{+}$precursor.(75,76) Fibroadipogenic precursor (FAP) found in skeletal muscle can differentiate into white adipocytes under certain conditions, including muscular dystrophy, obesity, and age-related sarcopenia.(77)

Lypolisis is a metabolic process which hydrolyze triglycerides into fatty acids (FA) and glycerols, thus the FA could be utilized either locally or by other organs. Lipolysis is induced by at least three major enzymes and associated cofactors, $\beta$-adrenergic signaling in the adipocyte, and other inducers (such as TNF- $\alpha$ ). (78) The primary cleavage performed by adipose triglyceride lipase (ATGL), cut triacylglycerol to diacylglycerols. The enzyme will infer when the second enzyme in the pathway, hormonesensitive lipase (HSL) ablated. HSL cut diacylglycerols into monoglyceride, and will be finalized by monoglyceride lipase (MGL) generating glycerol and FFAs. So, these three enzymes account for $>90 \%$ of the lipolytic activity in the adipocyte.(79) Insulin is the major physiological suppressor of lipolysis, but this process becomes impaired in obesity or IR condition. Insulin block lipolysis in many pathways. First, it activates phosphodiesterase 3b (PDE3b) via Aktmediated phosphorylationm it will reduce intracellular cyclic adenosine monophosphate (cAMP) levels and block protein kinase A (PKA) activation. $(80,81)$ Another noncanonical pathway block PKA selectively on Perilipin (Plin)1 through a phosphoinositide 3-kinases (PI3K)mediated, Akt-independent pathway.(82)

Recently, lipid droplet was known as a highly dynamic organelle with extraordinary conservation of its protein composition. More than 200 proteins were identified in adipocytes, including perilipin, the cell death-inducing DFF45-like effector (CIDE) family and various scaffolding proteins such as cavins and caveolins, associated with insulin sensitivity, and global energy homeostasis.(83) The protein known as adipokines, and they regulate energy storage and dissipation, which how ATs have a central role in energy homeostasis. Novel adipokines from white, brown and beige adipocytes keep popping up until recently, emphasize the AT role as endocrine organ. Identifying the specific receptors for each adipokine will give critical insight about energy homeostasis signaling pathways (Figure 4).(84)

Batokines is a specific name for adipokines secreted from BAT, and beige adipocytes, or so-called as thermogenic adipocytes, including FGF-21, neuregulin 4 (NRG4), vascular endothelial growth factor A (VEGFA) and bone morphogenetic protein $8 \mathrm{~B}$ (BMP-8B). $(85,86)$

Brown And Beige Fat: Development, Function And Therapeutic Potential

All three types of AT, white, brown, and brown-in-white or beige fat communicate extensively with other organs in the body to maintain energy homeostasis, including skin, liver, pancreas, muscle, and brain.(87) AT is dynamic. It ranges from 4 to $>4 \%$ of total body mass in adult humans. White fat as energy storage, while BAT and beige fat as 


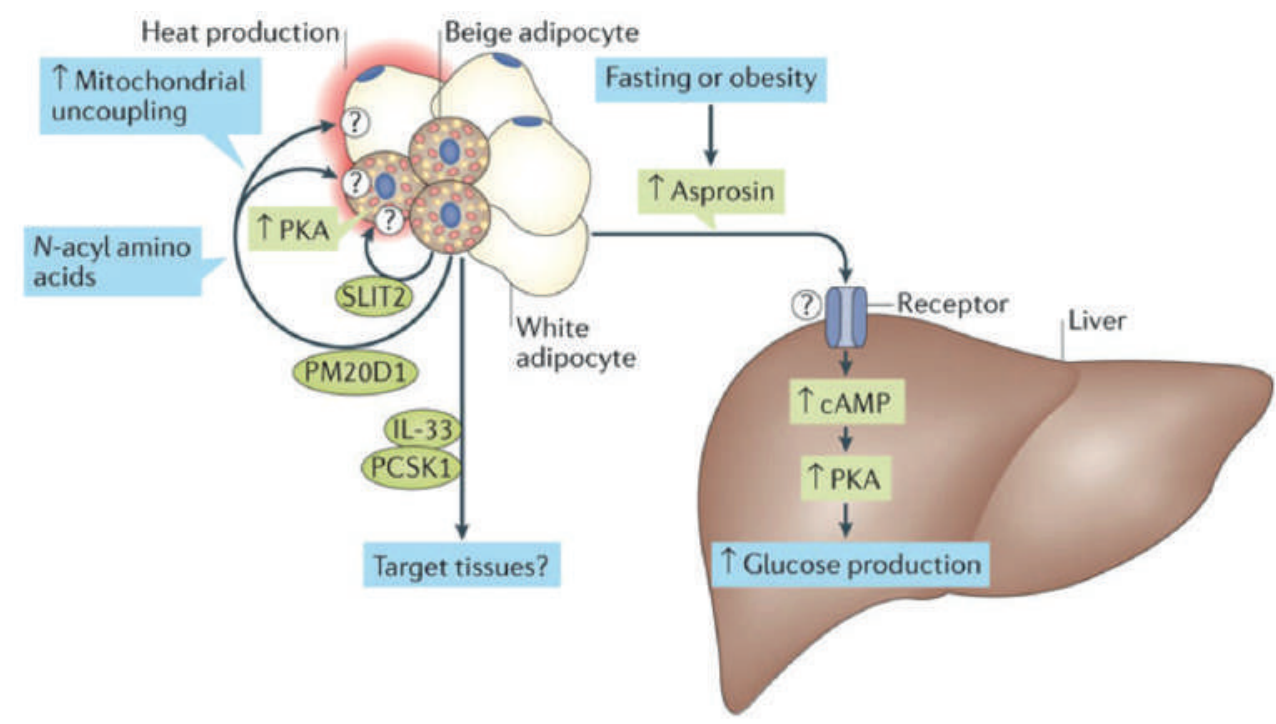

Figure 4. The regulation of systemic glucose homeostasis and insulin sensitivity through adipokines. PKA: protein kinase A; SLIT2: Slit homolog 2 protein; PM20D1: peptidase M20 domain containing 1; IL: interlukin; PCSK1: Proprotein Convertase Subtilisin/Kexin Type 1; cAPM: cyclic adenosine monophosphate.(84) (Adopted with permission from Springer Nature).

the whole-body energy homeostasis through non-shivering thermogenesis.(88) Thus, which different types of ATs will develop and function, and how is the mechanisms?(87)

Adipocytes, skeletal muscle cells, chondrocytes, and bone cells derived from mesenchymal progenitor cells, initiated by progressive fate restrictions to become each type of cell and followed by differentiation to acquire the morphological and functional characteristics of mature cell. BAT originate from the same precursor cells that also give rise to skeletal muscle cells and a subpopulation of white adipocytes $(72,89,90)$, in the embryonic mesoderm, during embryonic development before other fat depots, it was assumed the population of adipocytes are uniform. The precursors transiently express Myf5 and Pax7, the selective markers for skeletal myogenic cells in the mesoderm. BAT in rodents found majority in the interscapular region (interscapular, axillary and cervical pads), inlayed in and around deep back muscles, while in human infant BAT found in interscapular which regresses and is absent in adults. $(9,89)$ Consistent with the precursors suspected, BAT also express many muscle-specific genes, and the highly related mitochondrial proteomes between BAT and muscle. $(76,91)$ Some genes play roles in BAT vs muscle cell fate, including PRDM16, CCAAT-enhancer-binding proteins or (C/EBP)- $\beta$, euchromatic histone-lysine N-methyltransferase 1 (EHMT1), Ewing sarcoma gene (EWS), and Zfp516 $(72,92,93)$, especially EHMT1, an important coregulator of PRDM16, as well as EWS, is required for BAT development, and its deletion causes the ectopic expression of muscle genes in BAT (93). While PRDM16, not required for BAT development in mice, but can potently suppress muscle gene expression, suggested that its absence will induce some compensate mechanisms.(94) Zfp516 which can activate its transcriptional activity when interact with PRDM16. Brown fat differentiation could me induced by placenta-specific 8 (PLAC8) which is an upstream activator of C/EBP- $\beta$.(95) Oppositely, transducin-like enhancer protein 3 (TLE3) antagonizes PRDM16 activity thus suppresses brown fat differentiation and thermogenesis.(96)

Beige and brown adipocytes suspected to come from distinct cell lineages. However, it was not clear how is the cell hierarchy of beige adipocytes. It is found in the subcutaneous depot, but do not have a history of Myf5 expression although beige adipocytes traced by Myf5 activation was found in retroperitoneal white adipocytes. $(72,90,97)$ Thus, was it raised from white adipocytes transdifferentiation, or from precursors maturation de novo? Beige adipocytes arose from pre-existing (non-dividing) cells which is mature white adipocytes, in response to cold or $\beta 3$-adrenergic agonists $(73,74)$, however other study suggested that both cells have distinctive molecular profiles (98).

Notably, only the beige can activate uncoupling protein 1 (UCP1) expression in response to $\beta$-adrenergic stimulation. Expression of Ebf2 marks a subpopulation of adipogenic cells in white AT that are competent for UCP1 induction, while adipogenic cells with Ebf2-negative will turn into UCP1-negative adipocytes.(99) The precursor stage between brown/beige and white adipocytes are found to have different molecular signatures in adult humans. $(86,94)$. Beige adipocytes become very appealing, due to its highly inducible character, and the recent findings that adult BAT largely contains beige-like adipocytes. $(11,86,100)$ perhaps by inducing white AT beiging, obese and/or elderly people who lack sufficient amounts of active BAT depots will be advantaged. Both classical brown adipocytes and 
in beige adipocytes seemed to be affected by the same transcriptional and epigenetic regulators as seen in Figure 5.(101,102)

PPAR $-\gamma$ and the members of the C/EBP protein family were known to induce AT differentiation generally.(103) Both were suggested to activate specific thermogenic genes in brown and beige adipocytes. For instance, C/EBP- $\beta$ was found at higher amounts in BAT relative to white AT, and keep increasing in response to cold.(104) C/EBP- $\beta$ amount increased when $\beta$-adrenergic agonists in white AT induce the micro RNA (miRNA)-mediated degradation of Hoxc8, a repressor of C/EBP- $\beta$ transcription (105), and triggers a brown fat transcriptional profile $(104,106)$. Defect in $\mathrm{C} / \mathrm{EBP}-\beta$ is associated with defective thermogenesis. The activation of $\beta$-adrenergic will stimulate the master adipogenic factor, PPAR- $\gamma$ which binds and regulates distinct target genes in brown and white fat cells.(107-109)

Some new myokines recently identified, including Irisin and Meteorin-like (METRNL). These myokines are induced in muscle through the PGC- $1 \alpha$ pathway, and administration of both in mice could powerfully activates beige adipocyte development.(110,111) In adult humans, cold exposure increases circulating irisin.(112) Irisin propose the beige adipocyte-gene program in a cellautonomous manner, suggested through a selective receptor. Human irisin known to employ a noncanonical initiator codon (ATA) for its translation, might be subject to complex regulation in muscle and/or other tissues.(113) METRNL on the other hand, elicit beige adipocyte biogenesis by promoting an eosinophil-dependent activation of M2 antiinflammatory macrophages.(111) Exercise could induce some myokine such as IL-6, lactate and $\beta$-aminoisobutyric acid (BAIBA), and promote beige adipocyte biogenesis in the subcutaneous white AT depots in mice.(114-116)

Innate immune pathways also take a role in AT function control and at once the systemic glucose homeostasis. $(117,118)$ Group 2 innate lymphoid cells (ILC2) decreasing in white AT is correlated to obesity in humans and mice. (119) IL-33 is important for ILC2s maintenance in white AT, and also needed for beige adipocyte development in mice.(11,120). So, IL-33 administration will promote beige adipocyte biogenesis and increased whole-body energy expenditure, via some mechanisms, which are by increasing the production of Metenkephalin peptides by ILC2s (11), and by stimulating IL-4 secretion by eosinophils, which acts to promote the beige differentiation and proliferation from adipogenic precursor cells (120).

Non-shivering thermogenesis is an increase in metabolic heat production which is not associated with muscle activity, otherwise by lipolysis in brown adipocytes. ATGL or Comparative Gene Identification-58 (CGI-58) deletion, which control lipolysis in brown adipocyte, apparently does not affect cold-stimulated brown fat activity. $(121,122)$ Brown fat thermogenesis can be charged by circulating nutrients from diet or generated by lipolysis in white AT. For example, long chain fatty acids released from WAT are converted to acylcarnitines by liver, and in circulation taken up to fuel thermogenesis by the activated

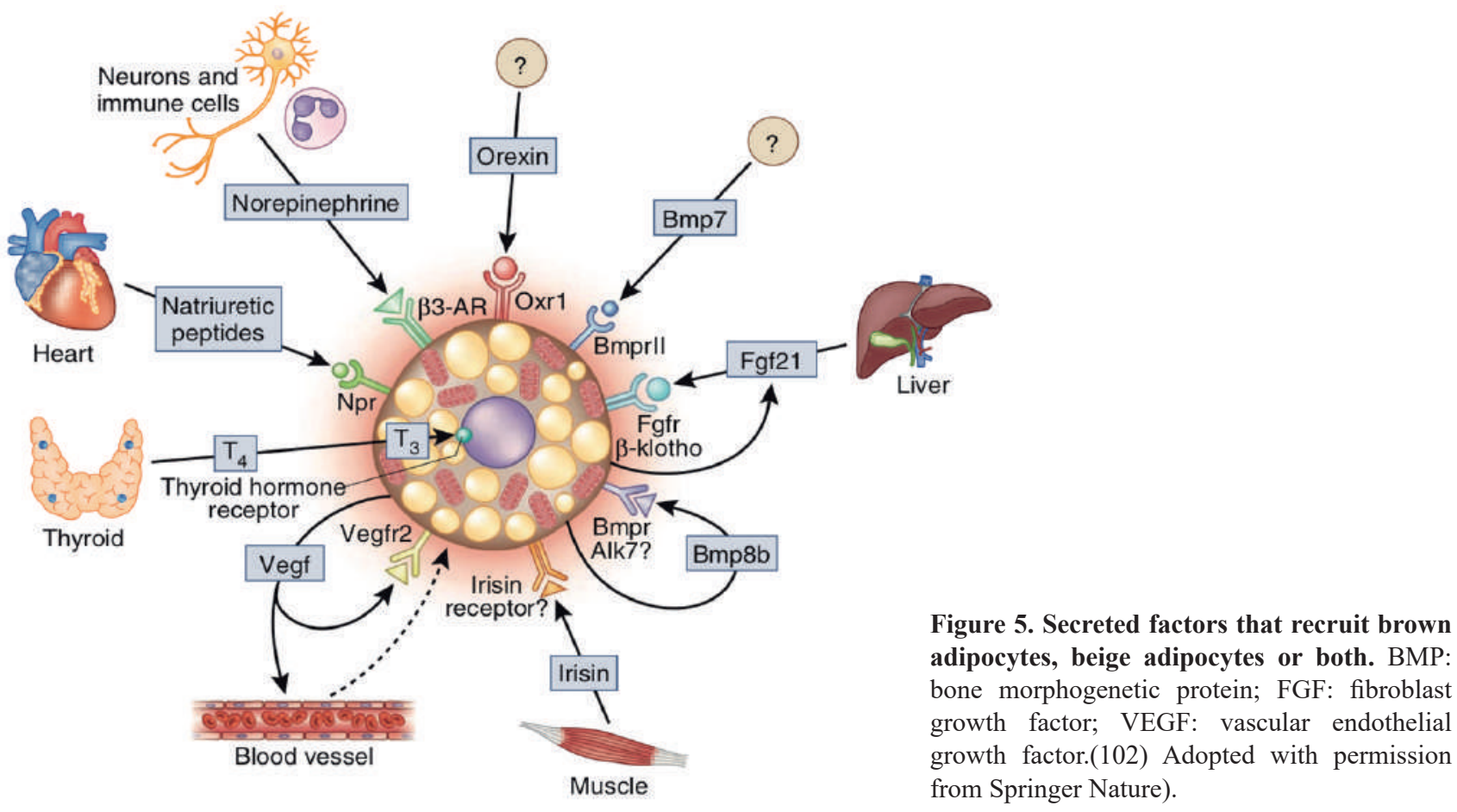


BAT.(123) Beige and brown adipocytes in maximum stimulation, can achieve similar thermogenic components like UCP1 $(11,124)$, although in its development, as in lineage tracing studies with Myh11Cre and Acta2Cre drivers, beige adipocytes share more similar history to muscle cells than brown adipocytes. $(125,126)$

Another mechanism for beige adipocyte energy expenditure happened through futile creatine cycling, by coordinated upregulation of creatine metabolism genes and creatine kinase activity.(127) Energy expenditures in mice were decreased when creatine synthesis in adipocytes was reduced, and they become sensitive to high- fat-dietinduced obesity (128), and this condition can be rescued by supplementation with dietary creatine, appearing creatine to regulate adaptive thermogenesis in vivo. Enzyme secreted by peptidase M20 domain-containing protein 1 (PM20D1) act bidirectional to fatty acids and amino acids. It promotes UCP1-independent uncoupling by regulating the production of $\mathrm{N}$-acyl amino acids such as $\mathrm{N}$-oleoyl phenylalanine. These N-lipidated amino acids uncouple mitochondrial respiration directly thus increase energy expenditure in obese animals.(129)

White AT adipokines have been widely known since a few decades ago, initiated by the discovery of leptin which show activity toward many biological processes including energy homeostasis. Batokines are adipokines secreted by BAT, perform autocrine (act on the cell that secretes them), paracrine (act on nearby cells), and endocrine (influence distant cells and organs) actions which were essential for tissue remodeling adaptations and adaptive non-shivering thermogenesis. Batokines' endocrine actions may have a role in peptidic and nonpeptidic molecules secreted by both brown and beige adipocytes performed autocrine signaling properties (130), for example the lipid 12,13-dihydroxy-9Zoctadecenoic acid (12,13-diHOME), produced in BAT after cold exposure activate its biosynthesis enzymes which acts to stimulate BAT activity by promoting FA uptake into brown adipocytes.(131) Endogenously activated biosynthesis of prostaglandin E2 (PGE2) induce white AT browning in mice and white fat trans-differentiation into beige adipocytes in human.(132,133) Prostaglandin synthesis enzyme lipocalin prostaglandin D synthase (L-PGDS) in insufficient levels may affect to BAT impairment.(134) Adenosine is released when brown adipocytes activates sympathetically, and in an autocrine manner, adenosine enhances thermogenic activation.(135) On the contrary, brown adipocytes induce endocannabinoid release thermogenically which acts as an autocrine negative feedback mechanism to control $\beta 3$ adrenergic stimulation during BAT activation and browning of white AT.(136) C-terminal fragment of SLIT2 (SLIT2-C) and PM20D1 are two autocrine factors with positive effects on BAT activity. SLIT2-C secreted from beige-adipocyte, cleaved from its full-length SLIT2 protein. It induces protein kinase A signaling downstream of the $\beta$-adrenergic pathway to promotes AT thermogenesis.(137) PM20D1 is a secreted enzyme. It converts fatty acids and amino acids into $\mathrm{N}$-acyl amino acids, which acts as endogenous, UCP1-independent, mitochondrial uncouplers and increase cellular respiration. (138) Paracrine action of BAT is shown in Figure 6A.

Several batokines targeting precursor cells (commitment) and/or preadipocytes (proliferation and/ or differentiation) to regulate brown and/or beige tissue adipogenesis.(139) Some batokines with positive effects including PGE2, follistatin, FGF-2, which is also secreted by brown adipocytes to induce more proliferation of preadipocytes in BAT $(140,141)$, and insulin-like growth factor (IGF)-1 induces proliferation and also differentiation (142). Some others suppress brown and/or beige adipogenesis such as growth differentiation factor 8 (GDF8) and endothelin-1. While Nitric oxide (NO), endogenously produced in brown adipocytes via adrenergic induction of NO synthase activities, inhibits proliferation but inducing the differentiation of preadipocytes in primary cultures. (140) Some factors found to be secreted by preadipocytes but not by mature adipocytes such as BMPs, cytokines, and plasminogen activator inhibitor 1 also contribute to brown adipogenesis. $(141,143,144)$ Endocrine actions of BAT are shown in Figure 6B.

Several batokines including METRNL and FGF21 released almost exclusively by beige AT $(11,111)$, was related to white AT 'browning', which also associated with healthy metabolic parameters in human. Thus, activating BAT thermogenesis with its batokines regard as a potential tools for metabolic therapies. Reviewing the characteristics of those AT (summarized in Table 1), a new hope was raised to utilized WAT browning to improve insulin sensitivity involving batokines and non-shivering thermogenesis as a strategy to fight against obesity and its comorbidities. However, more studies were need to highlight the best agents performed this action.

\section{Genetics and Epigenetics of Adipocyte Metabolism}

Obesity and T2DM known as the multifactorial diseases involving genetics and non-genetic (including epi-genetic) alteration in their etiology. The high rate of IR evidences 
A. Vascular

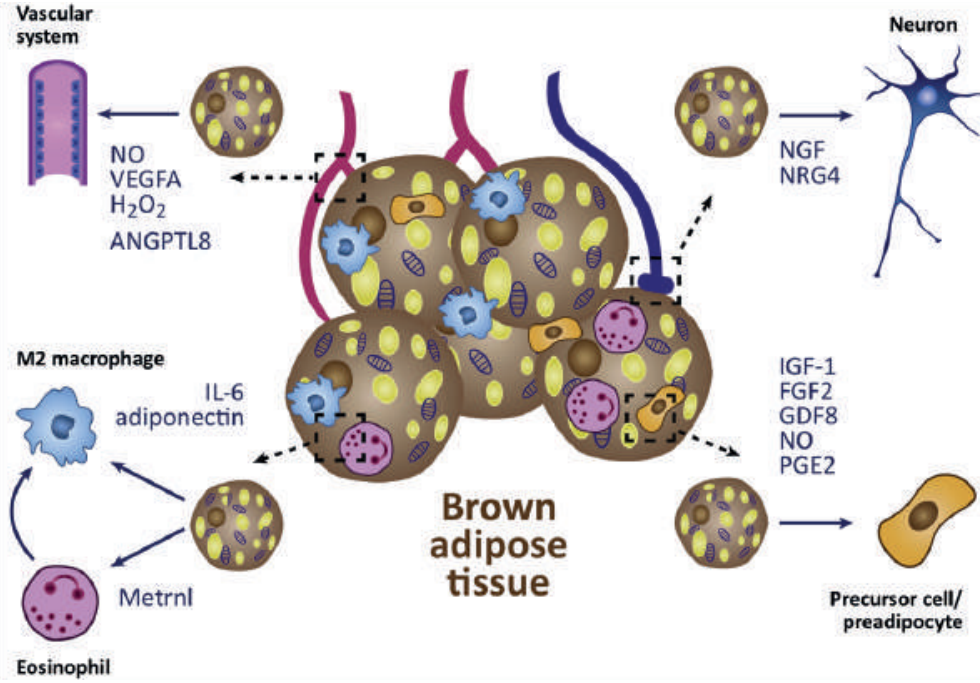

B.

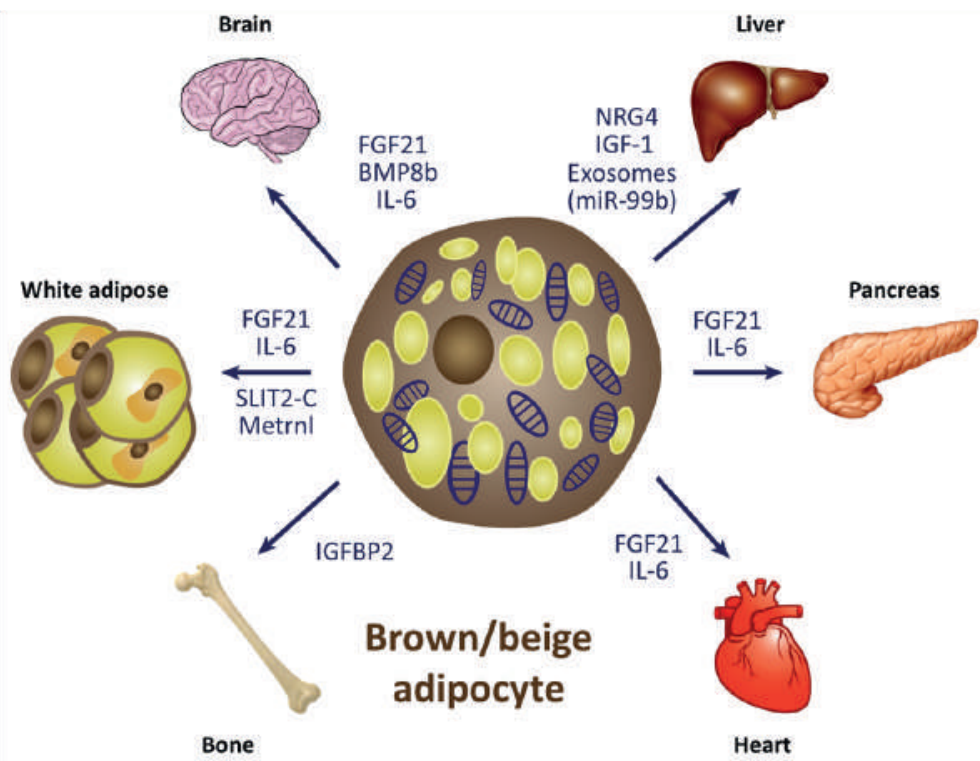

Figure 6. Paracrine and endocrine action of BAT and beige adipocyte.(130) A: Paracrinrelated actions; B: Endocrine-related actions.(Adopted with permission from Cell Press). NO: nitric oxide; VEGFA: vascular endothelial growth factor A; ANGPTL8: Angiopoietin Like 8; IL: interleukin; NGF: nerve growth factor; NRG4: Neuregulin 4; IGF: insulin-like growth factor; FGF: fibroblast growth factor; GDF: growth differentiation factor; PGE2: prostaglandin E2; BMP8b: bone morphogenetic protein 8B; SLIT2: Slit homolog 2 protein; IGFBP2:IGF binding protein.(130) (Adopted with permission from Cell Press). poses a great burden, especially when we implicate its comorbidity with obesity, T2DM, CVDs, and other metabolic diseases. As we discuss in the previous sections, adipocytes suggested to have an important role contribute to IR. Genome-wide association studies (GWAS) has mapped the genomes underlying obesity, T2DM, and IR, thus we could learn the genes implicated mechanisms in these diseases.

Some genes involving in energy balance regulation, variation in body mass index (BMI) have been studied since the pre-GWAS era from 1970 to 2005 and found 26 genes, many were implied in adipocyte biology. (145) As they were polygenic, metabolic diseases need a comprehensive gene-based identification. GWAS performed a large-scale sequencing to find any common variants represent the immense majority of genetic contribution to T2DM.(146) They found only a few rare variants affect metabolic disease, asserted GWAS to emphasize in the identification of common single-nucleotide polymorphisms (SNPs).(147)

Utilizing small cohort studies, GWAS found one locus that were strongly associated with metabolic disease, which is growth factor receptor bound protein 10 (GRB10), encodes an adaptor protein that regulates insulin receptor signaling. (148) Combination data from an European cohort, the Diabetes Genetics Initiative and the Genetic Investigation of Anthropometric Traits (GIANT) Consortium identified seven new loci trait to obesity.(149) The follow-up study demonstrated these loci increased AT mass, and thus total body weight but not lean tissue.(150) Five of these loci associated with food intake, explain a possible mechanisms for its correlation to obesity development.(151) Together with new T2DM loci, a strongly enriched effect of adipocytokine signaling was found.(152) 
Table 1. Characteristics of white, brown and beige adipose tissue.

\begin{tabular}{|c|c|c|c|}
\hline Characteristics & White Adipose Tissue & Brown Adipose Tissue & Beige Adipose Tissue \\
\hline Developing time & After birth, and throughout life & Fetal life & After birth, and throughout life \\
\hline Lineage & Multiple lineage & Myogenic lineage & Multiple lineage \\
\hline Biogenesis & Myf5- precursor cells & $\begin{array}{l}\text { Dermomyotomal precursors that } \\
\text { express En1, Myf5+, and Pax7 }\end{array}$ & $\begin{array}{l}\text { Myf5- cells, induced in respond to } \\
\text { some environmental condition \& } \\
\text { external cues (chronic cold } \\
\text { acclimation, exercises, long-term } \\
\text { treatment of PPAR-g agonist or b3- } \\
\text { adrenergic receptor agonists, etc) }\end{array}$ \\
\hline Location & Highly heterogenous & $\begin{array}{l}\text { Dedicated depots (infants), } \\
\text { relatively homogeneous }\end{array}$ & $\begin{array}{l}\text { Sporadically reside within WAT } \\
\text { depots }\end{array}$ \\
\hline Locus & Unilocular Lipids & Multilocular Lipids & Multilocular Lipids \\
\hline Mitochondria & Low & Abundant & Present (upon stimulation) \\
\hline Energy homeostasis & Energy Storage & $\begin{array}{l}\text { Energy expenditure via non- } \\
\text { shivering thermogenesis }\end{array}$ & $\begin{array}{l}\text { Energy expenditure via adaptive } \\
\text { thermogenesis }\end{array}$ \\
\hline $\begin{array}{l}\text { Thermogenic } \\
\text { mechanism }\end{array}$ & N/A & UCP1-dependent creatine cycling & $\begin{array}{l}\text { UCP1-independent (Ca2+ cycling, } \\
\text { creatine cycling) }\end{array}$ \\
\hline Maintenance & Transient into Beige & Constitutive & Transient into White \\
\hline Secretion & $\begin{array}{l}\text { Pro- and anti-inflammatory } \\
\text { adipocytokines; mostly induce } \\
\text { insulin resistance }\end{array}$ & $\begin{array}{l}\text { Batokines; induce insulin sensitivity } \\
\text { and improve metabolism }\end{array}$ & $\begin{array}{l}\text { Batokines; induce insulin sensitivity } \\
\text { and improve metabolism }\end{array}$ \\
\hline
\end{tabular}

DNA methylation plays important roles in many developmental processes including adipogenesis. Therefore, evidences demonstrated its involvement in metabolic perturbation, either in the abnormal development of AT or adult adipocytes dysfunction.(153-155) For instances, DNA methyltransferase (DNMT)1 is crucial for maintaining DNA methylation and repressive histone H3K9 methylation patterns prior to differentiation, and DNMT inhibition in multipotent $\mathrm{C} 3 \mathrm{H} 10 \mathrm{~T} 1 / 2$ cells and 3T3-L1 preadipocytes induces spontaneous differentiation in response to adipogenic inducers, suggesting it represses 3T3-L1 adipogenesis. (156-158) However, the genetic studies on DNMTs showed conflicting results. However, knocking down DNMT1 and -3a result in 3T3-L1 adipogenesis impairment.(159) In case of PPAR- $\gamma$ and C/EBP, both genes promoters are gradually demethylated during 3T3-L1 adipogenesis, according to the genes expression increased.(160,161) This accompany with the loss of repressive histone marks $(\mathrm{H} 3 \mathrm{~K} 9 \mathrm{me} 3)$ and the gain of active marks (e.g., H3K27ac and H3K4me3) (162), but the timing regulation is not fully understood.

Altered adipokines regulation found in obesity and obesity-related metabolic issues was some affected by regulated by DNA methylation.(162) Leptin is the key adipokine to maintain energy homeostasis by mediating tissue and brain communication. High leptin level typically associated with obesity, suggest as a result of leptin resistance. $(163,164)$ Recent studies tried to modify the epigenome via the manipulation of specific chromatin-modifying enzymes and resulted in important metabolic consequences such as causing or improving obesity and hyperglycemia.(165) Therefore, epigenetic mechanisms were involved in the risk of inherited diabetes and obesity.(166)

Back to brown and beige thermogenesis feature either via UCP1-dependent or UCP1-independent mechanisms (involving creatine substrate cycle and calcium futile cycle), brown and beige fat perform their effects on metabolic physiology by secreting endocrine factors and miRNA-containing exosomes that act as the communication vesicles to other tissues in the body. $(130,167,168)$ Brown fat secretes Neuregulin 4 (NRG-4) that attenuates hepatic lipogenesis and liver injury $(169,170)$, and releases microRNAs encapsulated in exosomes as important messengers for intertissue cross-talk $(171,172)$. A network of transcription factors and cofactors govern brown and beige fat development and maintenance including PRDM16 (71,94,173), early B-cell factor-2 (EBF2) (174), PGC-1 $\alpha$ 
(175), Zbtb7B (176), interferon regulatory factor 4 (IRF4) (177), Zfp516 (92), and EHMT1 (178), and they were interfaced with several long non-coding RNAs (lncRNAs) to regulate the adipocyte biology thermogenesis.

\section{Metabolomics of Adipose Tissue}

Since several decades ago, many interest has focus on metabolites produced by AT, especially to monitor obesityrelated metabolic disorders and to find novel diagnostic and prognostic biomarkers.(179) Metabolomic is a study to compare metabolic profiles of circulating metabolites between individuals, in this case refer to obese $v s$. lean. We knew so little about WAT metabolism due to methodological difficulties. A pioneer study investigated monozygotic (MZ) twins discordant for obesity with a $10-$ to $25-\mathrm{kg}$ weight difference. The acquired obesity was characterized by higher circulating proatherogenic and proinflammatory lysophosphatidylcholine species concentrations while antioxidative ether phospholipids were reduced.(180) Another study combined proteomics and metabolomics approaches and found several molecules differ the healthy lean individuals with obese.(181) They determined 163 metabolites in serum and found 12 metabolites metabolites significantly related to obesity. Glycine, glutamine, and glycerophosphatidylcholine 42:0 (PCaa 42:0) were higher, whereas PCaa 32:0, PCaa 32:1, and PCaa 40:5 were decreased in individuals with obesity compared with lean individuals.(181)

Branched-chain amino acid (BCAA) are a group of three essential amino acids: leucine, isoleucine and valine, functioning both as direct and/or indirect signals in downstream metabolic pathways. Interestingly, while BCAA optimal level was needed to improve metabolic health, increased BCAA plasma levels are generally associated to IR of T2DM. the mechanism could be explained by mammalian target of rapamycin complex 1 (mTORC1) activation by BCAAs.(182) A research demonstrated that constitutive mTORC1 activation can protects the mice from high fat diet-induced obesity, and AT inflammation.(183)

Several studies associated obesity with circulating metabolites of the TCA cycle. An investigation of BMI in the Framingham Heart Study associate with 69 of 217 studied metabolites and their pathways i.e., the citric acid cycle (e.g., isocitrate, $\alpha$-ketoglutarate, aconitate), the tryptophan pathway (e.g., kynurenine, kynurenic acid), and the urea cycle.(184) Obese subjects were differentiated into groups of MHO and metabolically unhealthy obese (MUHO) based on their whole-body IR, hepatic steatosis, and low-grade inflammation, generally correlated with cardiometabolic morbidity or mortality in metabolic unhealthy obese (MUHO) subjects compare to MHO. (185) Another metabolomic study with a total subjects of 10 insulin-resistant and 10 insulin-sensitive nondiabetic Caucasians with morbid obesity (BMI $>40 \mathrm{~kg} / \mathrm{m}^{2}$ ), matched for gender, age, BMI, and percentage of body fat. (186) Primary preadipocytes isolated and differentiated into adipocytes, and 280 metabolites were examined intracellularly, extracellularly, and in plasma. It was found that aspartate was reduced intracellularly to one-third in insulin-resistant adipocytes, describe a relative depletion of citric acid cycle metabolites and/or reduced aspartate uptake in MUHO.(186)

One main function of white AT is the conversion of glucose into FA and vice vers $a$, in order to regulate the energy demand and supply.(187) While performing its function completing the Cori cycle, white AT is highly oxygen dependent, reduced the $\mathrm{O} 2$ concentration on cultured human adipocytes in a level above hypoxia, led to major changes in adipocyte function, suggested that adipocytes are sensitive to small changes in $\mathrm{O}_{2}$ tension.(188) Obviously, metabolites of the glycolysis pathway have been associated with obesity in humans as well.(179)

An improved human AT metabolome mapping provides new insights and potential diagnostic, prognostic, and therapeutic tools for a variety of adipose-related disorders. Given that obesity has reached a pandemic scale and become quite a burden for public health worldwide, obesity-related alterations of AT metabolism biomarkers is of the utmost importance.(179)

\section{Conclusion}

In past few years, adipocytes classification, development, and differentiation has been significant changes. Some novel perspectives were provided on how adipocytes involved in a variety of homeostatic processes and communicate with other tissues, as well as how metabolic diseases rose from the alteration of these relationships and how we can manipulate the mechanisms.

\section{References}

1. Jonker JW, Suh JM, Atkins AR, Ahmadian M, Li P, Whyte J, et al. A PPAR $\gamma-F G F 1$ axis is required for adaptive adipose remodelling and metabolic homeostasis. Nature. 2012; 485: 391-4.

2. Saltiel AR, Kahn CR. Insulin signalling and the regulation of glucose and lipid metabolism. Nature. 2001; 414: 799-806. 
3. Kotas ME, Medzhitov R. Homeostasis, inflammation, and disease susceptibility. Cell. 2015; 160: 816-27.

4. Buettner C, Muse ED, Cheng A, Chen L, Scherer T, Pocai A, et al. Leptin controls adipose tissue lipogenesis via central, STAT3independent mechanisms. Nat Med. 2008; 14: 667-75. h

5. Scarpace PJ, Matheny M. Leptin induction of UCP1 gene expression is dependent on sympathetic innervation. Am J Physiol Endocrinol Metab. 1998; 275: E259-64.

6. Shen J, Tanida M, Niijima A, Nagai K. In vivo effects of leptin on autonomic nerve activity and lipolysis in rats. Neurosci Lett. 2007; 416: $193-7$.

7. Friedman JM. Obesity in the new millennium. Nature. 2000; 404: 632-4.

8. Fisher M, Kleiner S, Douris N, Fox EC, Mepani RJ, Verdeguer F, et al. FGF21 regulates PGC-1 and browning of white adipose tissues in adaptive thermogenesis. Genes Dev. 2012; 26: 271-81.

9. Lidell ME, Betz MJ, Leinhard OD, Heglind M, Elander L, Slawik M, et al. Evidence for two types of brown adipose tissue in humans. Nat Med. 2013; 19: 631-4.

10. Tews D, Schwar V, Scheithauer M, Weber T, Fromme T, Klingenspor $\mathrm{M}$, et al. Comparative gene array analysis of progenitor cells from human paired deep neck and subcutaneous adipose tissue. Mol Cell Endocrinol. 2014; 395: 41-50.

11. Wu J, Boström P, Sparks LM, Ye L, Choi JH, Giang AH, et al. Beige adipocytes are a distinct type of thermogenic fat cell in mouse and human. Cell. 2012; 150: 366-76.

12. Hotamisligil GS. Inflammation and metabolic disorders. Nature. 2006; 444: 860-7.

13. Lizcano F, Vargas D. Biology of beige adipocyte and possible therapy for type 2 diabetes and obesity. Int J Endocrinol. 2016; 2016: 9542061.

14. Van den Berg SM, van Dam AD, Rensen PCN, de Winther MPJ, Lutgens E. Immune modulation of brown(ing) adipose tissue in obesity. Endocr Rev. 2016; 38: 46-68.

15. Reilly SM, Saltiel AR. Adapting to obesity with adipose tissue inflammation. Nat Rev Endocrinol. 2017; 13: 633-43.

16. Crewe C, An A, Scherer PE. The omnious triad of adipose tissue dysfunction: inflammation, fibrosis, and impaired angiogenesis. J Clin Invest 2017; 127: 74-82.

17. Cinti S, Mitchell G, Barbatelli G, Murano I, Ceresi E, Faloia E, et al. Adipocyte death defines macrophage localization and function in adipose tissue of obese mice and humans. J Lipid Res. 2005; 46: 2347-55.

18. Fischer-Posovszky P, Wang QA, Asterholm IW, Rutkowski JM, Scherer PE. Targeted deletion of adipocytes by apoptosis leads to adipose tissue recruitment of alternatively activated M2 macrophages. Endocrinology. 2011; 152: 3074-81.

19. Strissel KJ, Stancheva Z, Miyoshi H, Perfield JW, DeFuria J, Jick $\mathrm{Z}$, et al. Adipocyte death, adipose tissue remodeling, and obesity complications. Diabetes. 2007; 56: 2910-8.

20. Jin C, Flavell RA. Innate sensors of pathogen and stress: linking inflammation to obesity. J Allergy Clin Immunol. 2013; 132: 28794.

21. Shi Y, Evans JE, Rock KL. Molecular identification of a danger signal that alerts the immune system to dying cells. Nature. 2003; 425: $516-21$.

22. Lamkanfi M, Dixit VM. Inflammasomes: guardians of cytosolic sanctity. Immunol Rev. 1009; 227: 95-105.

23. Vandanmagsar B, Youm Y-H, Ravussin A, Galgani JE, Stadler K, Mynatt RL, et al. The NLRP3 inflammasome instigates obesityinduced inflammation and insulin resistance. Nat Med. 2011; 17: $179-88$.
24. Kern PA, Saghizadeh M, Ong JM, Bosch RJ, Deem R, Simsolo RB. The expression of tumor necrosis factor in human adipose tissue. Regulation by obesity, weight loss, and relationship to lipoprotein lipase. J Clin Invest. 1995; 95: 2111-9.

25. Pasarica M, Sereda OR, Redman LM, Albarado DC, Hymel DT, Roan LE, et al. Reduced adipose tissue oxygenation in human obesity: evidence for rarefaction, macrophage chemotaxis, and inflammation without an angiogenic response. Diabetes. 2009; 58: 718-25.

26. Lawler HM, Underkofler CM, Kern PA, Erickson C, Bredbeck B, Rasouli N. Adipose tissue hypoxia, inflammation, and fibrosis in obese insulin- sensitive and obese insulin-resistant subjects. J Clin Endocrinol Metab. 2016; 101: 1422-8.

27. Imtiyaz HZ, Simon MC. Hypoxia-inducible factors as essential regulators of inflammation. Curr Top Microbiol Immunol. 2010; 345: $105-20$

28. Frasca D, Blomberg BB, Paganelli R. Aging, obesity, and inflammatory age-related diseases. Front in Immunol. 2017; 8: 1745 .

29. Freemerman AJ, Johnson AR, Sacks GN, Milner JJ, Kirk EL, Troester MA, et al. Metabolic reprogramming of macrophages: glucose transporter 1 (GLUT1)-mediated glucose metabolism drives a proinflammatory phenotype. J Biol Chem. 2014; 289: 7884-96.

30. Wen H, Ting JP, O'Neill LA. A role for the NLRP3 inflammasome in metabolic diseases - did Warburg miss inflammation? Nat Immunol. 2012; 13: 352-7.

31. Wen H, Gris D, Lei Y, Jha S, Zhang L, Huang MT, et al. Fatty acidinduced NLRP3-ASC inflammasome activation interferes with insulin signaling. Nat Immunol. 2011; 12: 408-15.

32. Lee HM, Kim JJ, Kim HJ, Shong M, Ku BJ, Jo EK. Upregulated NLRP3 inflammasome activation in patients with type 2 diabetes. Diabetes. 2013; 62: 194-204.

33. Skinner BM, Johnson EEP. Nuclear morphologies: their diversity and functional relevance. Chromosoma. 2016; 126: 195-212.

34. Williams AS, Kang L, Wasserman DH. The extracellular matrix and insulin resistance. Trends Endocrinol Metab. 2015; 26: 357-66.

35. Chun TH, Hotary KB, Sabeh F, Saltiel AR, Allen ED, Weiss SJ. A pericellular collagenase directs the 3-dimensional development of white adipose tissue. Cell. 2006; 125: 577-91.

36. Freund A, Orjalo AV, Desprez PY, Campisi J. Inflammatory networks during cellular senescence: causes and consequences. Trends Mol Med. 2010; 16: 238-46.

37. Olivieri F, Lazzarini R, Recchioni R, Marcheselli F, Rippo MR, Di Nuzzo S, et al. MiR-146a as marker of senescence-associated proinflammatory status in cells involved in vascular remodelling. Age. 2013; 35: 1157-72

38. Lanna A, Henson SM, Escors D, Akbar AN. The kinase p38 activated by the metabolic regulator AMPK and scaffold TAB 1 drives the senescence of human T cells. Nat Immunol. 2014; 15: 965-72.

39. Ley RE, Turnbaugh PJ, Klein S, Gordon JI. Microbial ecology: human gut microbes associated with obesity. Nature. 2006; 444: 1022-3.

40. Backhed F, Manchester JK, Semenkovich CF, Gordon JI. Mechanisms underlying the resistance to diet-induced obesity in germ-free mice. Proc Natl Acad Sci USA. 2007; 104: 979-84.

41. Neurath MF, Weigmann B, Finotto S, Glickman J, Nieuwenhuis E, Iijima $\mathrm{H}$, et al. The transcription factor T-bet regulates mucosal $\mathrm{T}$ cell activation in experimental colitis and Crohn's disease. J Exp Med. 2002; 195: 1129-43.

42. Garrett WS, Lord GM, Punit S, Lugo-Villarino G, Mazmanian SK, Ito $\mathrm{S}$, et al. Communicable ulcerative colitis induced by T-bet deficiency in the innate immune system. Cell. 2007; 131: 33-45.

43. Benezech C, Luu NT, Walker JA, Kruglov AA, Loo Y, Nakamura K, 
et al. Inflammation-induced formation of fat-associated lymphoid clusters. Nat Immunol. 2015; 16: 819-28.

44. Hotamisligil GS. Inflammation, metaflammation and immunometabolic disorders. Nature. 2017; 542: 177-85.

45. Hardy OT, Perugini RA, Nicoloro SM, Gallagher-Dorval K, Puri V, Straubhaar $\mathrm{J}$, et al. Body mass index-independent inflammation in omental adipose tissue associated with insulin resistance in morbid obesity. Surg Obes Relat Dis. 2011; 7: 60-7.

46. Arkan MC, Hevener AL, Greten FR, Maeda S, Li ZW, Long JM, et al. IKK- $\beta$ links inflammation to obesity-induced insulin resistance. Nat Med. 2005; 11: 191-8.

47. Hirosumi J, Tuncman G, Chang L, Görgün CZ, Uysal KT, Maeda $\mathrm{K}$, et al. A central role for $\mathrm{JNK}$ in obesity and insulin resistance. Nature. 2002; 420: 333-6.

48. Holland WL, Brozinick JT, Wang LP, Hawkins ED, Sargent KM, Liu $\mathrm{Y}$, et al. Inhibition of ceramide synthesis ameliorates glucocorticoid-, saturated-fat-, and obesity-induced insulin resistance. Cell Metab. 2007; 5: 167-79.

49. Shi H, Kokoeva MV, Inouye K, Tzameli I, Yin H, Flier JS. TLR4 links innate immunity and fatty acid-induced insulin resistance. J Clin Invest. 2006; 116: 3015-25.

50. Arner P. Catecholamine-induced lipolysis in obesity. Int J Obes Relat Metab Disord. 1999; 23 (Suppl. 1): 10-3.

51. Tjokroprawiro A. Recent Potential Effects of SGLT2-i and its FDC with Metformin-XR. PIT PERKENI JOGLOSEMAR-SENDOMET XI: Endocrine Disorder and Its Clinical Impact, 2019 Jul 12-14. Semarang: PIT PERKENI; 2019.

52. Knight ZA, Hannan KS, Greenberg ML, Friedman JM. Hyperleptinemia is required for the development of leptin resistance. PLoS ONE. 2010; 5: e11376.

53. Ozcan L, Ergin AS, Lu A, Chung J, Sarkar S, Nie D, et al. Endoplasmic reticulum stress plays a central role in development of leptin resistance. Cell Metab. 2009; 9(1): 35-51.

54. Saltiel AR. Insulin resistance in the defense against obesity. Cell Metab. 2012; 15: 798-804.

55. Björntorp P, Carlgren G, Isaksson B, Krotkiewski M, Larsson B, Sjöström L. Effect of an energy-reduced dietary regimen in relation to adipose tissue cellularity in obese women. Am J Clin Nutr. 1975; 28: 445-52.

56. Kral JG, Björntorp P, Scherstén T, Sjöström L. Body composition and adipose tissue cellularity before and after jejuno-ileostomy in severely obese subjects. Eur J Clin Invest. 1977; 7: 413-9.

57. Spalding KL, Arner E, Westermark PO, Bernard S, Buchholz BA, Bergmann $\mathrm{O}$, et al. Dynamics of fat cell turnover in humans. Nature. 2008; 453: 783-7.

58. Martinez-Santibañes G, Lumeng CNK. Macrophages and the regulation of adipose tissue remodeling. Anny Rev Nutr. 2014; 34: 57-76.

59. Lee MJ, Wu Y, Fried SK. Adipose tissue remodeling in pathophysiology of obesity. Curr Opin Clin Nutr Metab Care. 2010; 13: 371-6.

60. Suganami T, Ogawa Y. Adipose tissue macrophages: their role in adipose tissue remodeling. J Leukocyte Biol. 2010; 88: 33-9.

61. Sun K, Kusminski CM, Scherer PE. Adipose tissue remodeling and obesity. J Clin Invest. 2011; 121: 2094-101.

62. Sun K, Tordjman J, Clément K, Scherer PE. Fibrosis and adipose tissue dysfunction. Cell Metab. 2013; 18: 470-7.

63. Trayhurn P. Hypoxia and adipose tissue function and dysfunction in obesity. Physiol Rev. 2013; 93: 1-21.

64. Krishnan J, Danzer C, Simka T, Ukropec J, Walter KM, Kumpf S, et al. Dietary obesity-associated Hif1 activation in adipocytes restricts fatty acid oxidation and energy expenditure via suppression of the Sirt2-NAD+ system. Genes Dev. 2012;2 6: 259-70.
65. Halberg N, Khan T, Trujillo ME, Wernstedt-Asterholm I, Attie AD, Sherwani $\mathrm{S}$, et al. Hypoxia-inducible factor 1 induces fibrosis and insulin resistance in white adipose tissue. Mol Cell Biol. 2009; 29: 4467-83.

66. Denis GV, Obin MS. 'Metabolically healthy obesity': origins and implications. Mol Aspects Med. 2013; 34: 59-70.

67. Klöting N, Fasshauer M, Dietrich A, Kovacs P, Schön MR, Kern M, et al. Insulin-sensitive obesity. Am J Physiol Endocrinol Metab. 2010; 299: E506-15.

68. Cawthorn WP, Scheller EL, MacDougald OA. Adipose tissue stem cells meet preadipocyte commitment: going back to the future. J Lipid Res. 2011; 53: 227-46.

69. Rosen ED, Spiegelman BN. What we talk about when we talk about fat. Cell. 2014; 156: 20-44.

70. Billon N, Iannarelli P, Monteiro MC, Glavieux-Pardanaud C, Richardson WD, Kessaris N, et al. The generation of adipocytes by the neural crest. Development. 2007; 134: 2283-92.

71. Seale P1, Kajimura S, Yang W, Chin S, Rohas LM, Uldry M, et al. Transcriptional control of brown fat determination by PRDM16. Cell Metab. 2017; 6: 38-54.

72. Seale P, Bjork B, Yang W, Kajimura S, Chin S, Kuang S, et al. PRDM16 controls a brown fat/skeletal muscle switch. Nature. 2008; 454: 961-7.

73. Himms-Hagen J, Melnyk A, Zingaretti MC, Ceresi E, Barbatelli G, Cinti S. Multilocular fat cells in WAT of CL-316243-treated rats derive directly from white adipocytes. Am J Physiol Cell Physiol. 2000; 279: C670-81.

74. Vitali A, Murano I, Zingaretti MC, Frontini A, Ricquier D, Cinti S. The adipose organ of obesity-prone C57BL/6J mice is composed of mixed white and brown adipocytes. J Lipid Res. 2012; 53: 619-29.

75. Schulz TJ, Huang TL, Tran TT, Zhang H, Townsend KL, Shadrach $\mathrm{JL}$, et al. Identification of inducible brown adipocyte progenitors residing in skeletal muscle and white fat. Proc Natl Acad Sci USA. 2010; 108: 143-8.

76. Timmons JA, Wennmalm K, Larsson O, Walden TB, Lassmann T, Petrovic N, et al. Myogenic gene expression signature establishes that brown and white adipocytes originate from distinct cell lineages. Proc Natl Acad Sci USA. 2007; 104: 4401-6.

77. Natarajan A, Lemos DR, Rossi FMV. Fibro/adipogenic progenitors: A double-edged sword in skeletal muscle regeneration. Cell Cycle. 2010; 9: 2045-6.

78. Rydén M, Arner P. Tumour necrosis factor-? in human adipose tissue? from signalling mechanisms to clinical implications. J Intern Med. 2007; 262: 431-8.

79. Young SG, Zechner R. Biochemistry and pathophysiology of intravascular and intracellular lipolysis. Genes Dev. 2013; 27: 45984.

80. Degerman E, Landström TR, Wijkander J, Holst LS, Ahmad F, Belfrage $\mathrm{P}$, et al. Phosphorylation and activation of hormonesensitive adipocyte phosphodiesterase type 3B. Methods. 1998; 14: $43-53$.

81. Kitamura T, Kitamura Y, Kuroda S, Hino Y, Ando M, Kotani K, et al. Insulin-induced phosphorylation and activation of cyclic nucleotide phosphodiesterase $3 \mathrm{~b}$ by the serine-threonine kinase Akt. Mol Cell Biol. 1999; 19: 6286-96.

82. Choi SM, Tucker DF, Gross DN, Easton RM, DiPilato LM, Dean AS, et al. Insulin regulates adipocyte lipolysis via an Akt-independent signaling pathway. Mol Cell Biol. 2010; 30: 5009-20.

83. Konige M, Wang H, Sztalryd C. Role of adipose specific lipid droplet proteins in maintaining whole body energy homeostasis. Biochim Biophys Acta. 2014; 1842: 393-401.

84. Kajimura S. Advances in the understanding of adipose tissue biology. Nat Rev Endocrinol. 2017; 13: 69-70. 
85. Villarroya F, Cereijo R, Villarroya J, Giralt M. Brown adipose tissue as a secretory organ. Nat Rev Endocrinol. 2016; 13: 26-35.

86. Shinoda K, Luijten IH, Hasegawa Y, Hong H, Sonne SB, Kim M, et $a l$. Genetic and functional characterization of clonally derived adult human brown adipocytes. Nat Med. 2015; 21: 389-394.

87. Shapira SN, Seale P. Transcriptional control of brown and beige fat development and function. Obesity. 2019; 27: 13-21.

88. Ikeda K, Maretich P, Kajimura S. The common and distinct features of brown and beige adipocytes. Trends Endocrinol Metab. 2018; 29: 191-200.

89. Heaton JM. The distribution of brown adipose tissue in the human. J Anat. 1972; 112: 35-9.

90. Sanchez-Gurmaches J, Hung CM, Sparks CA, Tang Y, Li H, Guertin DA. PTEN loss in the Myf5 lineage redistributes body fat and reveals subsets of white adipocytes that arise from Myf5 precursors. Cell Metab. 2012; 16: 348-62.

91. Forner F, Kumar C, Luber CA, Fromme T, Klingenspor M, Mann M. Proteome differences between brown and white fat mitochondria reveal specialized metabolic functions. Cell Metab. 2009; 10: 324 35.

92. Dempersmier J, Sambeat A, Gulyaeva O, Paul SM, Hudak CSS, Raposo HF, et al. Cold-inducible Zfp516 activates UCP1 transcription to promote browning of white fat and development of brown Fat. Mol Cell. 2015; 57: 235-46.

93. Park JH, Kang HJ, Kang SI, Lee JE, Hur J, Ge K, et al. A multifunctional protein, EWS, is essential for early brown fat lineage determination. Dev Cell. 2013; 26: 393-404.

94. Harms MJ, Ishibashi J, Wang W, Lim HW, Goyama S, Sato T, et al. Prdm16 is required for the maintenance of brown adipocyte identity and function in adult mice. Cell Metab. 2014; 19: 593-604.

95. Jimenez-Preitner M, Berney X, Uldry M, Vitali A, Cinti S, Ledford $\mathrm{JG}$, et al. Plac8 is an inducer of $\mathrm{C} / \mathrm{EBP} \beta$ required for brown fat differentiation, thermoregulation, and control of body weight. Cell Metab. 2011; 14: 658-70.

96. Villanueva CJ, Vergnes L, Wang J, Drew BG, Hong C, Tu Y, et al. Adipose subtype-selective recruitment of TLE3 or Prdm16 by $\operatorname{PPAR} \gamma$ specifies lipid storage versus thermogenic gene programs. Cell Metab. 2013; 17: 423-35.

97. Sanchez-Gurmaches J, Hung CM, Sparks CA, Tang Y, Li H, Guertin DA. PTEN loss in the Myf5 lineage redistributes body fat and reveals subsets of white adipocytes that arise from Myf5 precursors. Cell Metab. 2012; 16: 348-62.

98. Wu J, Boström P, Sparks LM, Ye L, Choi JH, Giang AH, et al. Beige adipocytes are a distinct type of thermogenic fat cell in mouse and human. Cell. 2012; 150: 366-76.

99. Wang W, Kissig M, Rajakumari S, Huang L, Lim H, Won KJ, et al. Ebf2 is a selective marker of brown and beige adipogenic precursor cells. Proc Natl Acad Sci USA. 2014; 111: 14466-71.

100. Lee P, Werner CD, Kebebew E, Celi FS. Functional thermogenic beige adipogenesis is inducible in human neck fat. Int J Obes. 2013; 38: $170-6$

101. Kajimura S, Spiegelman BM, Seale P. Brown and beige fat: physiological roles beyond hear generation. Cell Metab. 2015; 22: 546-59.

102. Harms M, Seale P. Brown and beige fat: development, function and therapeutic potential. Nat Med. 2013; 19: 1252-63.

103. Rosen ED, MacDougald OA. Adipocyte differentiation from the inside out. Nat Rev Mol Cell Biol. 2006; 7: 885-96.

104. Kajimura S, Seale P, Kubota K, Lunsford E, Frangioni JV, Gygi SP, et al. Initiation of myoblast to brown fat switch by a PRDM16-C/ EBP- $\beta$ transcriptional complex. Nature. 2009; 460: 1154-8.

105. Mori M, Nakagami H, Rodriguez-Araujo G, Nimura K, Kaneda Y. Essential role for miR-196a in brown adipogenesis of white fat progenitor cells. PLoS Biology. 2012; 10: e1001314.

106. Carmona MC, Hondares E, Rodríguez de la Concepción ML, Rodríguez-sureda V, Peinado-onsurbe J, Poli V, et al. Defective thermoregulation, impaired lipid metabolism, but preserved adrenergic induction of gene expression in brown fat of mice lacking C/EBP $\beta$. Biochem J. 2005; 389: 47-56.

107. Cao W, Daniel KW, Robidoux J, Puigserver P, Medvedev AV, Bai X, et al. p38 mitogen-activated protein kinase is the central regulator of cyclic AMP-dependent transcription of the brown fat uncoupling protein 1 gene. Mol Cell Biol. 2004; 24: 3057-67.

108. Cao W, Medvedev AV, Daniel KW, Collins S. $\beta$-adrenergic activation of p38 MAP kinase in adipocytes. J Biol Chem. 2001; 276: 27077 82.

109. Tai AC, Jennermann C, Brown KK, Oliver BB, MacGinnitie MA, Wilkison WO, et al. Activation of the nuclear receptor peroxisome proliferator-activated receptor $\gamma$ promotes brown adipocyte differentiation. J Biol Chem. 1996; 271: 29909-14.

110. Boström P, Wu J, Jedrychowski MP, Korde A, Ye L, Lo JC, et al. A PGC1- $\alpha$-dependent myokine that drives brown-fat-like development of white fat and thermogenesis. Nature. 2012; 481: 463-8.

111. Rao RR, Long JZ, White JP, Svensson KJ, Lou J, Lokurkar I, et al. Meteorin-like is a hormone that regulates immune-adipose interactions to increase beige fat thermogenesis. Cell. 2014; 157: 1279-91.

112. Lee P, Linderman JD, Smith S, Brychta RJ, Wang J, Idelson C, et al. Irisin and FGF21 are cold-induced endocrine activators of brown fat function in humans. Cell Metab. 2014; 19: 302-9.

113. Jedrychowski MP, Wrann CD, Paulo JA, Gerber KK, Szpyt J, Robinson MM, et al. Detection and quantitation of circulating human irisin by tandem mass spectrometry. Cell Metab. 2015; 22: 734-40.

114. Knudsen JG, Murholm M, Carey AL, Biensø RS, Basse AL, Allen TL, et al. Role of IL-6 in exercise training- and cold-induced UCP1 expression in subcutaneous white adipose Tissue. PLoS ONE. 2014; 9: e84910.

115. Carriere A, Jeanson Y, Berger-Muller S, Andre M, Chenouard V, Arnaud E, et al. Browning of white adipose cells by intermediate metabolites: an adaptive mechanism to alleviate redox pressure. Diabetes. 2014; 63: 3253-65.

116. Roberts LD, Boström P, O'Sullivan JF, Schinzel RT, Lewis GD, Dejam A, et al. $\beta$-Aminoisobutyric acid induces browning of white fat and hepatic $\beta$-oxidation and is inversely correlated with cardiometabolic risk factors. Cell Metab. 2014; 19: 96-108.

117. Molofsky AB, Nussbaum JC, Liang H-E, Van Dyken SJ, Cheng LE, Mohapatra A, et al. Innate lymphoid type 2 cells sustain visceral adipose tissue eosinophils and alternatively activated macrophages. J Exp Med. 2013; 210: 535-49.

118. Wu D, Molofsky AB, Liang HE, Ricardo-Gonzalez RR, Jouihan HA, Bando JK, et al. Eosinophils sustain adipose alternatively activated macrophages associated with glucose homeostasis. Science. 2011; 332: $243-7$.

119. Brestoff JR, Artis D. Immune regulation of metabolic homeostasis in health and disease. Cell. 2015; 161: 146-60.

120. Lee MW, Odegaard JI, Mukundan L, Qiu Y, Molofsky AB, Nussbaum JC, et al. Activated type 2 innate lymphoid cells regulate beige fat biogenesis. Cell. 2015; 160: 74-87.

121. Schreiber R, Diwoky C, Schoiswohl G, Schrauwen P, Haemmerle G, Zechner R. Thermogenesis depends on ATGL-mediated lipolysis in cardiac muscle, but not brown adipose tissue. Cell Metab. 2017; 26: 753.e7-763.e7.

122. Shin H, Ma Y, Chanturiya T, Cao Q, Wang Y, Kadegowda AKG, et $a l$. Lipolysis in brown adipocytes is not essential for cold-induced thermogenesis in mice. Cell Metab. 2017; 26: 764-777.e5. 
123. Simcox J, Geoghegan G, Maschek JA, Bensard CL, Pasquali M, Miao $\mathrm{R}$, et al. Global analysis of plasma lipids identifies liver-derived acylcarnitines as a fuel source for brown fat thermogenesis. Cell Metab. 2017; 26: 509-522.e6.

124. Shabalina IG, Petrovic N, de Jong JM, Kalinovich AV, Cannon B, Nedergaard J. UCP1 in brite/beige adipose tissue mitochondria is functionally thermogenic. Cell Rep. 2013; 5: 1196-1203.

125. Long JZ, Svensson KJ, Tsai L, Zeng X, Roh HC, Kong X, et al. A smooth muscle-like origin for beige adipocytes. Cell Metab. 2014; 19: 810-20.

126. Berry DC, Jiang Y, Graff JM. Mouse strains to study cold-inducible beige progenitors and beige adipocyte formation and function. Nat Commun. 2016; 7: 10184.

127. Kazak L, Chouchani ET, Jedrychowski MP, Erickson BK, Shinoda K, Cohen $\mathrm{P}$, et al. A creatine-driven substrate cycle enhances energy expenditure and thermogenesis in beige fat. Cell. 2015; 163: 64355.

128. Kazak L, Chouchani ET, Lu GZ, Jedrychowski MP, Bare CJ, Mina $\mathrm{AI}$, et al. Genetic depletion of adipocyte creatine metabolism inhibits diet-induced thermogenesis and drives obesity. Cell Metab. 2017; 26: 693.

129. Long JZ, Svensson KJ, Bateman LA, Lin H, Kamenecka T, Lokurkar IA, et al. The secreted enzyme PM20D1 regulates lipidated amino acid uncouplers of mitochondria. Cell. 2016; 166: 424-35.

130. Villarroya F, Gavalda-Navarro A, Peyrou M, Villarroya J, Giralt M. The lives and times of brown adipokines. Trends Endocrinol Metab. 2017; 28: 855-67.

131. Lynes MD, Leiria LO, Lundh M, Bartelt A, Shamsi F, Huang TL, et $a l$. The cold-induced lipokine 12,13- diHOME promotes fatty acid transport into brown adipose tissue. Nat Med. 2017; 23: 631-7.

132. García-Alonso V, López-Vicario C, Titos E, Morán-Salvador E, González-Périz A, Rius B, et al. Coordinate functional regulation between microsomal prostaglandin e synthase-1 (mPGES-1) and peroxisome proliferator-activated receptor $\gamma(\operatorname{PPAR} \gamma)$ in the conversion of white-to-brown adipocytes. J Biol Chem. 2013; 288: 28230-42.

133. García-Alonso V, Titos E, Alcaraz-Quiles J, Rius B, Lopategi A, López-Vicario C, et al. Prostaglandin E2 exerts multiple regulatory actions on human obese adipose tissue remodeling, inflammation, adaptive thermogenesis and lipolysis. PLoS ONE. 2016; 11: e0153751.

134. Virtue S, Feldmann H, Christian M, Tan CY, Masoodi M, Dale M, et al. A new role for lipocalin prostaglandin D synthase in the regulation of brown adipose tissue substrate utilization. Diabetes. 2012; 61: 3139-47.

135. Gnad T, Scheibler S, von Kügelgen I, Scheele C, Kilić A, Glöde A, et al. Adenosine activates brown adipose tissue and recruits beige adipocytes via A2A receptors. Nature. 2014; 516: 395-9.

136. Krott LM, Piscitelli F, Heine M, Borrino S, Scheja L, Silvestri C, et al. Endocannabinoid regulation in white and brown adipose tissue following thermogenic activation. JouJ Lipid Res. 2016; 57: 46473.

137. Svensson KJ, Long JZ, Jedrychowski MP, Cohen P, Lo JC, Serag S, et al. A secreted Slit2 fragment regulates adipose tissue thermogenesis and metabolic function. Cell Metab. 2016; 23: 454-66.

138. Long JZ, Svensson KJ, Bateman LA, Lin H, Kamenecka T, Lokurkar IA, et al. The secreted enzyme PM20D1 regulates lipidated amino acid uncouplers of mitochondria. Cell. 2016; 166: 424-35.

139. Nisoli E, Clementi E, Tonello C, Sciorati C, Briscini L, Carruba MO. Effects of nitric oxide on proliferation and differentiation of rat brown adipocytes in primary cultures. Br J Pharmacol. 1998; 125: 888-94.
140. Yamashita H, Sato Y, Kizaki T, Oh-ishi S, Nagasawa J, Ohno H. Basic fibroblast growth factor (bFGF) contributes to the enlargement of brown adipose tissue during cold acclimation. Pflugers Arch. 1994; 428: $352-6$

141. Pellegrinelli V, Carobbio S, Vidal-Puig A. Adipose tissue plasticity: how fat depots respond differently to pathophysiological cues. Diabetologia. 2016; 59: 1075-88.

142. Lorenzo M, Valverde AM, Teruel T, Benito M. IGF-I is a mitogen involved in differentiation-related gene expression in fetal rat brown adipocytes. J Cell Biol. 1993; 123: 1567-75.

143. Cereijo R, Giralt M, Villarroya F. Thermogenic brown and beige/brite adipogenesis in humans. Ann Med. 2014; 47: 169-77.

144. Orava J, Nuutila P, Lidell ME, Oikonen V, Noponen T, Viljanen T, et al. Different metabolic responses of human brown adipose tissue to activation by cold and insulin. Cell Metab. 2011; 14: 272-9.

145. Ghosh S, Bouchard C. Convergence between biological, behavioural and genetic determinants of obesity. Nat Rev Genet. 2017; 18: 73148.

146. Fuchsberger C, Flannick J, Teslovich TM, Mahajan A, Agarwala $\mathrm{V}$, Gaulton KJ, et al. The genetic architecture of type 2 diabetes. Nature. 2016; 536: 41-7.

147. Friesen M, Cowan CA. Adipocyte metabolism and insulin signaling perturbations: insights from genetics. Trends Endocrinol Metab. 2019; 30: 396-406.

148. Rampersaud E, Damcott CM, Fu M, Shen H, McArdle P, Shi X, et $a l$. Identification of novel candidate genes for type 2 diabetes from a genome-wide association scan in the old order amish: evidence for replication from diabetes-related quantitative traits and from independent populations. Diabetes. 2007; 56: 3053-62.

149. Thorleifsson G, Walters GB, Gudbjartsson DF, Steinthorsdottir V, Sulem P, Helgadottir A, et al. Genome-wide association yields new sequence variants at seven loci that associate with measures of obesity. Nat Genet. 2008; 41: 18-24.

150. Renström F, Payne F, Nordström A, Brito EC, Rolandsson O, Hallmans G, et al. Replication and extension of genome-wide association study results for obesity in 4923 adults from northern Sweden. Hum Mol Genet. 2009; 18: 1489-96.

151. Bauer F, Elbers CC, Adan RA, Loos RJ, Onland-Moret NC, Grobbee $\mathrm{DE}$, et al. Obesity genes identified in genome-wide association studies are associated with adiposity measures and potentially with nutrient-specific food preference. Am J Clin Nutr 2009; 90: 951-9.

152. Large-scale association analysis provides insights into the genetic architecture and pathophysiology of type 2 diabetes. Nat Genet. 2012; 44: 981-90.

153. Ma X, Kang S. Functional implications of DNA methylation in adipose biology. Diabetes. 2019; 68: 871-8.

154. Smith ZD, Meissner A. DNA methylation: roles in mammalian development. Nat Rev Genet. 2013; 14: 204-20.

155. Pinnick KE, Karpe F. DNA methylation of genes in adipose tissue. Proc Nutr Soc 2011; 70: 57-63.

156. Taylor SM, Jones PA. Multiple new phenotypes induced in and 3T3 cells treated with 5-azacytidine. Cell. 1979; 17: 771-9.

157. Bowers RR, Kim JW, Otto TC, Lane MD. Stable stem cell commitment to the adipocyte lineage by inhibition of DNA methylation: role of the BMP-4 gene. Proc Natl Acad Sci USA. 2006; 103: 13022-7.

158. Londono Gentile T, Lu C, Lodato PM, Tse S, Olejniczak SH, Witze ES, et al. DNMT1 is regulated by ATP-citrate lyase and maintains methylation patterns during adipocyte differentiation. Mol Cell Biol. 2013; 33: 3864-78.

159. Yang X, Wu R, Shan W, Yu L, Xue B, Shi H. DNA methylation biphasically regulates 3T3-L1 preadipocyte differentiation. Mol Endocrinol. 2016; 30: 677-87. 
160. Fujiki K, Shinoda A, Kano F, Sato R, Shirahige K, Murata M. PPARg-induced PARylation promotes local DNA demethylation by production of 5-hydroxymethylcytosine. Nat Commun. 2013; 4: 2262.

161. Li J, Zhang N, Huang X, Xu J, Fernandes JC, Dai K, et al. Dexamethasone shifts bone marrow stromal cells from osteoblasts to adipocytes by C/EBPalpha promoter methylation. Cell Death Dis. 2013; 4: e832.

162. Ouchi N, Parker JL, Lugus JJ, Walsh K. Adipokines in inflammation and metabolic disease. Nat Rev Immunol. 2011; 11: 85-97.

163. Pan WW, Myers MG Jr. Leptin and the maintenance of elevated body weight. Nat Rev Neurosci. 2018; 19: 95-105.

164. Myers MG Jr, Leibel RL, Seeley RJ, Schwartz MW. Obesity and leptin resistance: distinguishing cause from effect. Trends Endocrinol Metab. 2010; 21: 643-51.

165. Rosen ED. Epigenomic and transcriptional control of insulin resistance. J Intern Med. 2016; 280: 443-56.

166. Rosen ED, Kaestner KH, Natarajan R, Patti MR, Sallari R, Sander M, et al. Epigenetics and epigenomics: implications for diabetes and obesity. Diabetes. 2018; 67: 1923-31.

167. Sun L, Lin JD. Function and mechanism of long noncoding RNAs in adipocyte biology. Diabetes. 2019; 68: 887-96.

168. Bertholet AM, Kazak L, Chouchani ET, Bogaczyńska MG, Paranjpe I, Wainwright GL, et al. Mitochondrial patch clamp of beige adipocytes reveals UCP1-positive and UCP1-negative cells both exhibiting futile creatine cycling. Cell Metab. 2017; 25: 811-22.e4.

169. Chen Z, Wang G-X, Ma SL, Jung DY, Ha H, Altamimi T, et al. $\mathrm{Nrg} 4$ promotes fuel oxidation and a healthy adipokine profile to ameliorate diet-induced metabolic disorders. Mol Metab. 2017; 6: $863-72$.

170. Guo L, Zhang P, Chen Z, Xia H, Li S, Zhang Y, et al. Hepatic neuregulin 4 signaling defines an endocrine checkpoint for steatosisto-NASH progression. J Clin Invest. 2017; 127: 4449-61.

171. Chen Y, Buyel JJ, Hanssen MJW, Siegel F, Pan R, Naumann J, et al. Exosomal microRNA miR-92a concentration in serum reflects human brown fat activity. Nat Commun. 2016; 7: 11420.

172. Thomou T, Mori MA, Dreyfuss JM, Konishi M, Sakaguchi M, Wolfrum $\mathrm{C}$, et al. Adipose-derived circulating miRNAs regulate gene expression in other tissues. Nature. 2017; 542: 450-5.

173. Cohen P, Levy JD, Zhang Y, Frontini A, Kolodin DP, Svensson KJ, et al. Ablation of PRDM16 and beige adipose causes metabolic dysfunction and a subcutaneous to visceral fat switch. Cell. 2014; 156: 304-16.

174. Rajakumari S, Wu J, Ishibashi J, Lim HW, Giang AH, Won KJ, et al. EBF2 determines and maintains brown adipocyte identity. Cell Metab. 2013; 17: 562-74.

175. Lin J, Handschin C, Spiegelman BM. Metabolic control through the
PGC-1 family of transcription coactivators. Cell Metab. 2005; 1: $361-70$.

176. Li S, Mi L, Yu L, Yu Q, Liu T, Wang G-X, et al. Zbtb7b engages the long noncoding RNA Blnc1 to drive brown and beige fat development and thermogenesis. Proc Natl Acad Sci USA. 2017; 114: E7111-20.

177. Kong X, Banks A, Liu T, Kazak L, Rao RR, Cohen P, et al. IRF4 is a key thermogenic transcriptional partner of PGC-1a. Cell. 2014; 158: 69-83.

178. Ohno H, Shinoda K, Ohyama K, Sharp LZ, Kajimura S. EHMT1 controls brown adipose cell fate and thermogenesis through the PRDM16 complex. Nature. 2013; 504: 163-7.

179. Kucena J, Spacil Z, Friedecky D, Novak J, Pekar M, Bienertova-Vasku J. Human white adipose tissue metabolome: Current perspective. Obesity. 2019; 26: 1870-8.

180. Pietiläinen KH, Sysi-Aho M, Rissanen A, Seppänen-Laakso T, YkiJärvinen H, Kaprio J, et al. Acquired obesity is associated with changes in the serum lipidomic profile independent of genetic effects - a monozygotic twin study. PLoS One. 2007; 2: e218.

181. Oberbach A, Blüher M, Wirth H, Till H, Kovacs P, Kullnick Y, et al. Combined proteomic and metabolomic profiling of serum reveals association of the complement system with obesity and identifies novel markers of body fat mass changes. J Proteome Res. 2011; 10: 4769-88.

182. Yoon MS. The emerging role of branched-chain amino acids in insulin resistance and metabolism. Nutrients. 2016; 8: 405.

183. Paschoal VA, Amano MT, Belchior T, Magdalon J, Chimin P, Andrade ML, et al. mTORC1 inhibition with rapamycin exacerbates adipose tissue inflammation in obese mice and dissociates macrophage phenotype from function. Immunobiology. 2017; 222: 261-71.

184. Ho JE, Larson MG, Ghorbani A, Cheng S, Chen M-H, Keyes M, et al. Metabolomic profiles of body mass index in the Framingham Heart Study reveal distinct cardiometabolic phenotypes. PLoS One. 2016; 11: $\mathrm{e} 0148361$.

185. Brestoff JR, Artis D. Immune regulation of metabolic homeostasis in health and disease. Cell. 2015; 161: 146-60.

186. Böhm A, Halama A, Meile T, Zdichavsky M, Lehmann R, Weigert $\mathrm{C}$, et al. Metabolic signatures of cultured human adipocytes from metabolically healthy versus unhealthy obese individuals. PLoS One 2014; 9: e93148.

187. DelMar RM, Sabater D, Fernández-López JA, Remesar X, Alemany M. Glycerol production from glucose and fructose by 3T3-L1 cells: a mechanism of adipocyte defense from excess substrate. PLoS One. 2015; 10: e0139502.

188. Wood IS, Stezhka T, Trayhurn P. Modulation of adipokine production, glucose uptake and lactate release in human adipocytes by small changes in oxygen tension. Pflugers Arch. 2011; 462: 469-77. 